\title{
Examining the Wates Principles for Large Private Companies as a Social Contract for Corporate Citizenship
}

\section{Roger M Barker* and Iris H-Y Chiu**}

\section{Introduction}

In December 2018, a set of principles for corporate governance aimed at large private companies was unveiled in the UK, the culmination of an industry-led effort. ${ }^{1}$ These standards would also facilitate compliance with the mandatory obligation under the UK Companies Act for large companies, whether public or private, to publicly disclose their corporate governance arrangements. $^{2}$

The reform is a pioneering measure, as soft law for companies' corporate governance has only been introduced for listed companies so far. The UK's reform followed from a significant corporate failure, BHS, in 2016. ${ }^{3}$ BHS was a large private company with at least 11,000 employees, and its failure had significant and adverse stakeholder impact.

Although significant corporate failures in the UK have given rise to both business and social concerns, the UK has always looked to improving corporate governance as a proportionate remedy ${ }^{4}$ instead of imposing hard laws and regulations. The development of corporate governance policy incorporates government, business and wider collaboration, ${ }^{5}$ but crucially allows business to 'heal itself' by internal changes it can make. This ethos has continued in the production of the Wates Principles for Large Private Companies, which is the institutional response to the social outcry against $\mathrm{BHS}^{\prime}$ collapse. This soft law instrument ${ }^{6}$ is part of wider corporate governance reforms ${ }^{7}$ led by the now-ousted May government which made its mark on reforming the corporate sector to become more responsible and inclusive. Large private companies can choose to adopt the Principles or otherwise and if they do, they should 'apply and explain'. ${ }^{8}$

\footnotetext{
* Managing Director, Governomics Ltd, Honorary Associate, Centre for Ethics and Law, University College London.

** Professor of Corporate Law and Financial Regulation, University College London, also the corresponding author. We would like to thank two anonymous reviewers for their very helpful comments on an earlier draft and all errors and omissions are ours.

${ }^{1}$ The Code known as the Wates Principles is the product of deliberations and consultations led by a Coalition Group chaired by James Wates CBE, Group Chairman of the Wates Group, a private family-owned construction and property development company in the UK with an operating income of close to f50m in 2017.

2 Part 8, Schedule 7, Companies Act 2006 amended by the Companies (Miscellaneous Reporting) Regulations 2018.

${ }^{3}$ The collapse of Monarch Airlines in October 2017, the UK's largest ever airline bankruptcy (which led to 2,300 job losses and the stranding of more than 110,000 customers overseas), also contributed to policy concerns surrounding private company governance.

${ }^{4}$ Iris H-Y Chiu, “Learning from the UK in the Proposed Shareholders' Rights Directive 2014? European Corporate Governance Regulation from a UK Perspective" (2015) 114 ZVgIRWiss 1 at Section A.

${ }^{5}$ Alan Dignam, “Capturing Corporate Governance: The End of the UK Self-regulating System" (2007) 4 International Journal of Disclosure and Governance 24.

${ }^{6}$ Wates Principles (2018) at page 8 for example states the Principles as a supportive but not mandatory instrument for corporations reporting on their corporate governance arrangements. But adopters should 'apply and explain'.

${ }^{7}$ BEIS, Corporate Governance Reform: The Government's Response to the Green Paper for Consultation (Aug 2017) at ch3.

${ }^{8}$ Above.
} 
The Wates Principles introduce six high-level principles that are highly non-prescriptive for large private companies. These are supplemented with suggested best practices when companies report against them, but the suggested best practices are not comprehensively granular and companies have discretion as to how they may wish to report.

The six principles are:

(a)a large private company should have a clear and well-defined purpose and leadership in the company should ensure that strategy and culture are fostered towards delivering the purpose effectively;

(b) a large private company should have an effective Board that is balanced, competent, diverse and effective. There is no compulsion towards appointing independent directors but suggestion of this being a good practice is made;

(c) a large private company should ensure that individual directors and the Board collectively have a clear understanding of their responsibilities. Suggested best practice include committees on the Board to deal with particular responsibilities such as Board succession and remuneration but these are not mandatory;

(d)a large private company should seek its long-term sustainable success and the Board should engage in appropriate risk management. Suggested best practice includes the institution of a company-wide internal control framework but is not highly prescriptive;

(e) a large private company should set appropriate and fair levels of remuneration for directors and senior executives. Suggested best practice includes making remuneration structures and policies more transparent;

(f) a large private company should consider its impact on present and future stakeholders. Suggested best practice encourages companies to engage with stakeholders in dialogue but is not highly prescriptive. $^{9}$

It remains uncertain if the Principles are self-regulatory. ${ }^{10}$ Where publicly-listed companies are concerned, the Corporate Governance Code which applies to them is enforced by their securities investors ${ }^{11}$ as a check on management. Investors are normally not part of management, and usually dispersed and hold minority stakes. In that way, corporate governance standards are the basis for companies' and investors' mutual expectations as to how the company should be governed. ${ }^{12}$ Where

\footnotetext{
${ }^{9}$ See The Wates Corporate Governance Principles for Large Private Companies at https://www.frc.org.uk/getattachment/31dfb844-6d4b-4093-9bfe-19cee2c29cda/Wates-CorporateGovernance-Principles-for-LPC-Dec-2018.pdf.

${ }^{10}$ This is because it is yet uncertain who would 'enforce' these principles, in a closely-held company in particular. The Financial Reporting Council does not, unlike the Listing Authority in the case of the UK Corporate Governance Code, have enforcement powers against corporations in relation to the reporting.

${ }^{11}$ Such as the shareholder spring that began in 2012 as shareholders scrutinised executive pay, and see Carsten Gerner-Buerle and Tom Kirschmaier, 'Say on Pay: Do Shareholders Care?' (ECGI Working Paper 2019) at https://ecgi.global/sites/default/files/working_papers/documents/finalgerner-beuerlekirchmaier.pdf; also Moore's analysis of how shareholders revolted at Marks \& Spencer for not adhering to the Corporate Governance Code, Marc Moore, "'Whispering Sweet Nothings": The Limitations of Informal Conformance in UK Corporate Governance' (2009) 9 Journal of Corporate Law Studies 77.

12 The first Cadbury Code of Corporate Governance in the UK is framed around shareholder-management relations, see discussion in ch2, Iris H-Y Chiu, The Foundations and Anatomy of Shareholder Activism (Oxford: Hart 2010).
} 
large private companies are concerned, they may be wholly or dominantly-owned by controlling interests such as families, founders, states, private equity funds and parent companies, and controlling interests are often represented on management. These corporate governance structures are perceived to give rise to different corporate governance concerns, i.e. divergence of interests between controlling and minority shareholders (if any) and with stakeholders (the BHS case, as will be examined shortly). ${ }^{13}$ Hence, what would corporate governance reforms achieve in the case of large private companies? Amongst whom would these standards create mutual soft law expectations so that the companies can be called to account? Controlling shareholders may be the source of concern in these companies and to whom can we make them accountable? In other words, although it is relatively clear from practice and theory ${ }^{14}$ that corporate governance standards create healthy bridges of engagement and accountability between Boards and shareholders, it is less obvious how such accountability mechanisms would apply in a large private company where controlling shareholders wield influence over Boards. We suggest that in light of the context surrounding the reforms, principally lessons from the demise of BHS, these standards should be seen as reflecting stakeholder and wider social expectations of how large private companies should be run. In other words, we posit that these standards are part of the framing of business-society relations between large private companies and society. ${ }^{15}$

We examine the Wates Principles in this light, and utilise the theoretical framework of the social contract ${ }^{16}$ and its more recent application in the concept of social citizenship ${ }^{17}$ to analyse the nature of the Principles and their achievements. We argue in Section 1 that the social contract theoretical framework is the appropriate theoretical framework for examining the Wates Principles, as business-society relations were identified to be the basis for the government's corporate governance reforms. ${ }^{18}$ Using this theoretical framework, and recent thought development in corporate social citizenship theory, which is grounded in social contract theory, we develop a set of benchmark norms in order to evaluate the achievements of the Wates Principles in Section 2. These benchmark norms will also be empirically informed as we are of the view that a purely theoretical approach to showing how large private companies should conduct themselves is incomplete without showing what large private companies already conceive of their positions in the social fabric. We conduct a brief empirical survey of large private companies socially-facing practices in order to derive empirical insight that feeds into the derivation of our benchmark norms against which to measure the Wates Principles. These benchmark norms will be categorised as substantive ${ }^{19}$ and

\footnotetext{
${ }^{13}$ R La Porta, F Lopez-de-Silanes and A Shleifer, 'Corporate Ownership around the World' (1999) 106 Journal of Finance 471.33

${ }^{14}$ such as agency theory between Boards and shareholders, see M Jensen and W Meckling, "Theory of the Firm: Managerial Behavior, Agency Costs and Ownership Structure" (1976) 3 Journal of Financial Economics 305.

${ }^{15}$ Some may hesitate to accept that business-society relations are part of corporate law or governance, but see an argument for the inherent dynamism and indeterminacy of the boundaries of corporate law and governance, Christopher M Bruner, 'What is the Domain of Corporate Law?' (2019) at https://papers.ssrn.com/sol3/papers.cfm?abstract_id=3308611, based on wider market, social, historical and cultural contexts, defying an economically insular or autopoeitic conception of corporate law and governance. ${ }^{16}$ Dating back to Thomas Donaldson, Corporations and Morality (Prentice Hall 1982), and to be further explored.

${ }^{17}$ Broadly defined, see Greg Urban, 'Why For-Profit Corporations and Citizenship?' in Corporations and Citizenship (University of Pennsylvania Press 2014) at ch1, and not confined to the controversial Matten and Crane exposition, to be explored.

18 To be explored.

19 Meaning that the norms deal with a definite or specific standard of conduct or outcome, such as respect for human rights as posited by many commentators, eg John Douglas Bishop, 'For-Profit Corporations in a Just
} 
procedural..$^{20}$ Our discussion shows that the Principles are somewhat consistent with procedural norms but ultimately fall short of the social expectations for the corporate governance of large private companies. The Principles are nevertheless accompanied by informal rhetoric towards more precise forms of socially desirable behaviour such as 'restraint in pay' ${ }^{21}$ and may be referred to as a 'starting point'. ${ }^{22}$ Suggestions for improvement are made and we conclude briefly in Section 3.

\section{Why Social Contract Theory should be the Framework for Analysing the Wates Principles}

This Section argues that contrary to instinctive thinking that tends to liken the Wates Principles to the UK's Corporate Governance Code ${ }^{23}$ the Principles should not theoretically be regarded as located in the same paradigm as that for the UK Corporate Governance Code. We should not view the Wates Principles as merely revolving around the Board and shareholders, as is the focus of the Corporate Governance Code. ${ }^{24}$ The theoretical 'relocation' of the paradigm for the Wates Principles is, in our view, necessary to advance an evaluation of the Wates Principles on different terms.

\section{The Need for an Alternative Theoretical Location for the Wates Principles}

The likening of the Wates Principles to the UK Corporate Governance Code may be regarded as natural. First, the Principles may be seen as an extension from the institution of corporate governance norms for publicly traded companies in the UK Corporate Governance Code. The perspective that can be taken is: what may be optimal norms for governing a publicly traded company can be close to what would work for a large private company, as there may be similar economic characteristics in terms of size, scale, corporate structures etc. ${ }^{25}$ In this sense, although the UK would be the first to introduce a set of governance principles for large private companies, the extension in scope can be perceived to be an incremental step. The broad similarity of coverage and character of norms between the Wates Principles and the UK Corporate Governance Code reinforces the 'incremental' perception, as both deal with Board composition, transparency and accountability, strategy and objectives of the company and remuneration. Optimal corporate governance norms largely revolve around 'monitoring elements' on the Board, ${ }^{26}$ developing a clear 'purpose' for strategy and ensuring appropriate remuneration policies.

Society: A Social Contract Argument Concerning the Rights and Responsibilities of Corporations' (2008) 18 Business Ethics Quarterly 191, to be explored.

${ }^{20}$ Meaning that the norms deal with means or procedures by which to determine allocation of rights, resources and outcomes, such as the Rawlsian conditions under the veil of ignorance, and also discussed in the Integrated Social Contracts Theory, Thomas Donaldson and Thomas Dunfee, 'Integrative Social Contracts Theory: A Communitarian Conception of Economic Ethics' (2005) 11 Economics and Philosophy 85.

21 'Private firms must show pay restraint and hire skilled Boards' (Daily Mail 13 June 2018). Although the Daily Mail may justifiably be regarded as not understanding what the Principles say, the interpretation could be regarded as perhaps drawing from social expectations.

22 Eg the ICAEW's view at https://www.icaew.com/-/media/corporate/files/technical/icaewrepresentations/2018/icaew-rep-112-18-wates-corporate-governance-principles.ashx. ${ }^{23}$ https://www.frc.org.uk/directors/corporate-governance-and-stewardship/uk-corporate-governance-code.

24 The UK Corporate Governance Code is centred upon Boards and shareholders from 1992-2018. In 2018, new provisions were introduced to allow employee participation at Board level, Provisions 5, 6, UK Corporate Governance Code 2018. The Code itself is in a period of change in terms of its nature and purpose but this is an issue that can only be fully explored elsewhere.

${ }^{25}$ the public corporation is said to be in decline as companies choose to delist in order to enjoy more flexibility and be subject to less regulatory constraint, Michael C Jensen, 'The Eclipse of the Public Corporation' (1989) 9 Harvard Business Review at https://hbr.org/1989/09/eclipse-of-the-public-corporation.

${ }^{26}$ Mathias Siems, 'Convergence in Corporate Governance: A Leximetric Approach' (2010) 35 Journal of Corporation Law 729. 
The perception of similarity also serves an instrumental purpose of maintaining the institutional congeniality of the reform. UK policy-makers' response to corporate scandals since the Cadbury Code 1991 has always involved the corporate sector in reflecting upon itself and deriving solutions in a quasi self-regulatory manner. The fall of $\mathrm{BCCl}$ and Polly Peck due to management fraud in 1991 triggered a thorough examination of honest financial reporting by companies and Sir Adrian Cadbury was asked to lead a committee to look into that issue. The Cadbury committee however rightly identified that the governance of the company was integral to a sound financial reporting process, and that internal governance and controls had to be in place before integrity in the output of financial reporting could be secured. Hence, much of the Cadbury Report ${ }^{27}$ dealt with a model of good governance for companies, including Board effectiveness, composition including non-executive directors, the formation of independent committees of the Board, the appointment of auditors and how audit services should be provided, and the role of shareholders. The product of the Cadbury Committee's deliberations was the Cadbury Code of Corporate Governance, the pioneering piece of soft law on corporate governance in the UK. The Code is subject to a comply-or-explain regime, and they are adopted into the Listing Rules which require explanation for deviation if the standards in the Code are not complied with by Premium-listed companies on the London Stock Exchange. The Cadbury Code of Corporate Governance was a pragmatic and proportionate approach to addressing business scandals in the UK, shaped by a matrix of influences largely based in the UK and was in keeping with the British tradition of 'negotiated' regulation- this means that businesses in the UK are not imposed with regulatory intervention unless necessary, and such regulatory intervention is shaped largely by bottom-up influences from the industry itself. ${ }^{28}$

This trend of domestic generation of corporate governance reforms continued ${ }^{29}$ most developments being in soft law rather than in legislation, except for the introduction of the Directors'

Remuneration Report Regulations 2002 and the binding shareholders' vote on remuneration on a three-yearly basis in 2015. ${ }^{30}$

The perception of institutional congeniality between the Wates Principles and the UK Corporate Governance Code is important to allow the Principles to remain largely derived from the business sector and maintaining alignment with the Corporate Governance Code, which has already achieved traction in the perception of the investor community and markets. ${ }^{31}$

However, the perception of similarity should be challenged. First, the UK's Corporate Governance Code is very much based on the acceptance of an economic theoretical framework of corporate governance $^{32}$ for the Berle-Means' company where ownership and control are separated. In a

\footnotetext{
${ }^{27}$ Adrian Cadbury, Report of the Committee on the Financial Aspects of Corporate Governance (Dec 1992). ${ }^{28}$ S. Wilks, "The Amoral Corporation and British Utility Regulation" (1997) 2 New Political Economy 280, quoted in Alan Dignam, "Exporting Corporate Governance: UK Regulatory Systems in a Global Economy" (2000) Company Lawyer 70, and this concept is also again extensively discussed in A Dignam, "Capturing Corporate Governance: The End of the UK Self-regulating System" (2007) 4 International Journal of Disclosure and Governance 24.

${ }^{29}$ See Iris H-Y Chiu, "Learning from the UK in the Proposed Shareholders' Rights Directive 2014? European Corporate Governance Regulation from a UK Perspective" (2015) 114 ZVgIRWiss 1 at Section A.

${ }^{30}$ S439A, Companies Act 2006.

${ }^{31}$ Klaus J Hopt, 'Comparative Corporate Governance: The State of the Art and International Regulation' (2011) 59 American Journal of Comparative Law 1.

${ }^{32}$ As shareholders bear the open-ended possibility of loss of their capital and are 'residual claimants', the key risk identified to them is the 'agency problem' as managers have discretion to abuse the application of capital and deviate from shareholders' interests, see M Jensen and W Meckling, "Theory of the Firm: Managerial Behavior, Agency Costs and Ownership Structure" (1976) 3 Journal of Financial Economics 305.
} 
company where there is dispersed shareholding separate from managerial roles, an 'agency' situation exists for shareholders and optimal norms of corporate governance therefore place shareholders at the central position of corporate objective and managerial accountability. ${ }^{33}$ Hence the norms in corporate governance revolve around subjecting managerial power to appropriate control. Such controlling mechanisms include the institution of independent directors as a monitoring influence, the institution of Board committees for the dispersal of executive managerial power, the pay-for-performance principle that aligns managerial incentives to those of shareholders' concern for corporate wealth maximisation, ${ }^{34}$ and accountability to shareholders at formal and informal meetings ${ }^{35}$ and through reporting. The large private company is usually structured in a different manner, with concentrated ownership of shares and concurrent assumption of managerial power by shareholders.

Many large private companies are closely-held or have significant shareholders, perhaps to protect such companies from market pressures and to ensure founders', families' and large owners' (such as private equity funds) interests are met in controlling and managing the companies. These corporate governance structures are perceived to give rise to different corporate governance concerns, such as differences in interest between controlling and minority shareholders (if any) and the potential exploitation of stakeholders in such a context of power concentration. ${ }^{36}$ For example, minority shareholders may be exploited by a discriminatory dividend policy ${ }^{37}$ or by squeezeouts. ${ }^{38}$ Although company law provides remedies for minority shareholders to redress their grievances, fallouts between controlling and minority shareholders inevitably lead to the exit of minority shareholders. ${ }^{39}$ Stakeholders can also be exploited due to incomplete contractual protections in a relational contracting context with the firm, exacerbated by the concentration of power in the firm, as will be discussed in relation to the findings made after the BHS collapse. It is doubtful that corporate governance norms that are theoretically based on an economic model of the dispersed corporation which is publicly traded applies to the large private corporation. Shareholder primacy in the dispersed corporation is a theoretical balancing mechanism against the concentration of power in managerial hands, but the same primacy of shareholders would only reinforce the existing concentration of power in a large private corporation. Can mechanisms designed to empower the dispersed minority shareholder in a publicly traded corporation be similarly applied to the large private corporation without perverse effects? At this point we note that the Wates Principles do contain explicit and different exhortations in relation to controlling shareholders, but we argue in Section 3 that these norms can be enhanced further if we evaluate them against in a different theoretical framework.

The economic and private nature of the Corporate Governance Code is based on a certain assumption of ownership structure that allows the two organs of the company ie the Board and shareholders, to be 'pitted against' each other (not necessarily in an adversarial manner). It is this

\footnotetext{
${ }^{33}$ Above.

${ }^{34}$ Hence the efficient bargaining paradigm in light of shareholders' residual claimant status is that managers must manage the company towards shareholder wealth maximisation, see Frank $\mathrm{H}$ Easterbrook and Daniel $\mathrm{R}$ Fischel, "The Corporate Contract" in The Economic Structure of Corporate Law (Cambridge Mass: Harvard University Press 1991) at 1ff.

${ }^{35}$ Informal engagement is encouraged in the UK Stewardship Code.

${ }^{36}$ Discussed in Roger M Barker and Iris H-Y Chiu, 'Protecting Minority Shareholders in Blockholder-Controlled Companies - Critically Evaluating the UK's Enhanced Listing Regime' (2015) Capital Markets Law Journal 98.

${ }^{37}$ Routledge v Skerritt [2019] EWHC 573.

${ }^{38}$ Brown v British Abrasive Wheel Co. Brown v British Abrasive Wheel Co [1919] 1 Ch 290 and the more recent Arbuthnott $v$ Bonnyman \& Ors [2015] EWCA Civ 536.

${ }^{39}$ The buyout order being the main remedy under s996 of the Companies Act 2006.
} 
binary that allows for relationships and mechanisms of monitoring and accountability to be fostered. We do not in this article discuss further our views on this binary concept in corporate governance, ${ }^{40}$ but in a large private corporation, the same relational binary does not exist, or at least, we need to look at different relational binaries if we are to utilise the same conceptions of monitoring and accountability to moderate the exercises of concentrated power.

Hence, we ask where alternative relational binaries may be located for the effective deployment of monitoring and accountability mechanisms. In a large private corporation, the alternative relational binaries may be located in controlling-minority shareholder relationships. However, this is not a stable or archetypal relational binary to adopt as some large private corporations have no minority shareholders and are wholly owned. Or, even if there are minority shareholders, they may be affiliates or members of the same controlling family, or minority shareholders can be made to exit. ${ }^{41}$ Further, UK company law has entrenched legal principles on the right of the majority shareholders to rule ${ }^{42}$ giving minority shareholders only personal remedies and not governance-based remedies. ${ }^{43}$ In this manner, the controlling-minority relational binary is not a workable alternative paradigm for developing corporate governance norms based on monitoring and accountability tenets.

It is arguable that the alternative paradigm in a large private corporation lies in the relational binary between the firm and its stakeholders and social community, or even the firm and the state. For example, the support of stakeholders in relation to the production process or as consumers of the firm's products or services, and the social licence to operate ${ }^{44}$ are crucial to the large private corporation's success. Such success is the foundation upon which the power structures in the large private corporation can continue to be sustained. If productive or consumer stakeholders desert the firm ${ }^{45}$ or its social licence to operate comes under question, the power structures in the firm's viability would come under threat. Further, in relation to the alternative relational binary paradigm of the firm and the state, the state's industrial policy and the firm's business-government relations ${ }^{46}$ would be crucial to the firm's success as well as the maintenance of power by controlling shareholders.

The large private corporation is arguably located in alternative relational paradigms that are no longer binary but multi-level and actored. In this manner, it is less theoretically tenable to situate the large private corporation in an insular relational binary, such as between shareholders and managers in the dispersed publicly traded corporation. The relational paradigms in which the large private corporation is located would feature a wider range of socially and institutionally contextualised entities. It may be argued that it is ironic that the large private corporation that intends to insulate itself from investors' and market pressures could be theoretically placed in a position where its governance norms should be based on a broad relational paradigm. However, two clarifications are

\footnotetext{
${ }^{40}$ For example, other conceptions of corporate governance such as the stakeholder-based framework have been discussed in relation to the same relational binary, see Iris $\mathrm{H}-\mathrm{Y}$ Chiu, 'Operationalising A Stakeholder Conception in Company Law' (2017) 10 Law and Financial Markets Review 173.

${ }^{41}$ By squeezeouts that are legitimate eg Sidebottom v Kershaw, Leese \& Co Ltd [1920] 1 Ch 154, or even after a dispute, a court-ordered buyout under s996, Companies Act 2006.

42 Eg the 'second prong' of the rule in Foss v Harbottle (1843) 67 ER 189.

${ }^{43}$ Case law relating to personal remedies under s994, Companies Act 2006.

${ }^{44}$ Karin Buhmann, 'Public Regulators and CSR: The 'Social Licence to Operate' in Recent United Nations Instruments on Business and Human Rights and the Juridification of CSR' (2016, Journal of Business Ethics, forthcoming) at http://ssrn.com/abstract=2705360.

${ }^{45}$ Assuming that there is a choice, however limited.

${ }^{46}$ Eg see extensive discussions in David Coen et al (eds), The Oxford Handbook of Business and Government (Oxford: OUP 2010).
} 
made. The first is that the broad relational paradigm of state, stakeholders and social community are also relevant to the publicly traded corporation (no matter its ownership structure) but its shareholders, representing a body of market discipline, are often seen as most optimally positioned for governance. ${ }^{47}$ There are plenty of discussions in academic literature relating to broader notions of governance for publicly-traded companies. ${ }^{48}$ Further, even the UK Corporate Governance Code is beginning to reform its 'binary' relational framework as its recent revamp in 2018 has allowed the introduction of employee voice in the Code. The UK Corporate Governance Code now provides that employee voice should be channelled to the Board by one of three options: appointing an employee representative director, dedicating a non-executive director to employee concerns or instituting an employee advisory council to the Board..$^{49}$ This development can be more fully discussed elsewhere but the point made here is that there are signs that even the UK Corporate Governance Code is giving way to a more pluralistic recognition of actorhood in corporate governance.

Secondly, the theoretical location of the large private corporation in broad relational paradigms would less likely apply to smaller and less influential private companies whose relations with government, stakeholders and society are more limited. Hence the self-regulation of internal corporate governance for these entities would likely remain appropriate and the theoretical framing for the large private corporation is unlikely to extend disproportionately to small companies.

We proceed to argue that the alternative theoretical framework of the social contract theory is more appropriate for examining the Wates Principles and its achievements. We suggest that the Principles ought to embody terms that accord with the theoretical construct of the social contract between large businesses and society, because of two reasons. One relates to the genesis of the policy reform underlying the Wates Principles and the other relates to the universal applicability of the theoretical framework. ${ }^{50}$

\section{Context for Policy Reform Leading to Wates Principles}

The Wates Principles have been developed against a backdrop of social disappointment with business, in particular relating to the collapse of British Home Stores (BHS) in 2016. BHS was a large private company in the retail sector. It was a listed company until 2000 when it was sold to the Arcadia Group controlled by Sir Philip Green's family. In 2015, BHS was sold for $€ 1$ to Dominic Chappell, and it collapsed a year later. As the BHS collapse affected many stakeholders such as employees, pensioners and suppliers, its collapse became the subject of a Parliament inquiry. The Parliament Committee expressed that '[the collapse of BHS] encapsulated many of our ongoing concerns about the regulatory and cultural framework in which business operates, including the ethics of business behaviour, the governance of private companies, the balance between risk and

\footnotetext{
${ }^{47}$ The notion underlying the Stewardship Code for shareholders, see Iris H-Y Chiu, 'Turning Institutional Investors into "Stewards"- Exploring the Meaning and Objectives in "Stewardship"' (2013) Current Legal Problems 1.

${ }^{48}$ Such as stakeholder and communitarian theories of corporate governance, see overview and citations in Iris H-Y Chiu, 'Operationalising A Stakeholder Conception in Company Law' (2017) 10 Law and Financial Markets Review 173.

${ }^{49}$ https://www.frc.org.uk/directors/corporate-governance-and-stewardship/uk-corporate-governance-code.

${ }^{50}$ Which is developed from Donaldson's 1982 treatise, see above with refinements introduced by subsequent commentators.
} 
reward, mergers and acquisitions practices, the governance and regulation of workplace pension schemes, and the sustainability of defined benefit pensions. ${ }^{.51}$

BHS, a retail chain initially sold to a company controlled by Sir Philip Green's family, was profitable at first as Green introduced extensive cost-cutting measures and improved efficiency. However, The Parliament Inquiry found that he did not grow the business but extracted the company's profits as significant amounts of dividends. Such extraction was made in spite of the squeezes put on suppliers and creditors, no improvement in wages for employees and a mounting pension deficit in the company's defined benefit scheme. The Parliament Committee clearly criticised these practices, and the ultimate sale of the company to Dominic Chappell in $2015 .{ }^{52}$ The latter had little relevant experience in the retail sector and was disqualified as director after BHS' collapse. ${ }^{53}$ The social cost of the collapse was immense and it is doubtful if affected stakeholders would fully recover. The Committee observed:

BHS's demise has created many losers. Its 11,000 employees face an uncertain future seeking work or facing unemployment. Its 20,000 current and future pensioners face substantial cuts to their entitlements. Their pension costs will now be met through levies paid by other pension schemes, including many attached to small companies. Companies in BHS's supply-chain, and their employees, have already been hit too. The reputation of business, the engine of prosperity, has been damaged, to the dismay of responsible investors, owners and business leaders. The episode is not, however, without winners. Many of those closest to the decisions that led to the collapse of BHS have walked away greatly enriched despite the company's failure. ${ }^{54}$

The Parliament Inquiry into BHS was the forerunner to the government's Green Paper on Corporate Governance Reforms, which explored the need to look into higher minimum standards for corporate governance and reporting by large private companies. Although the development of corporate governance standards had been in the realm of publicly listed companies where 'the agency problem' between powerful management and dispersed shareholders ${ }^{55}$ needed to be addressed, such standards were also relevant to large private companies, on the basis of a wider slate of stakeholders' interests, viz 'good governance can go beyond the relationship between the owners and the managers of a company, and that there are other stakeholders, including employees,

\footnotetext{
${ }^{51}$ House of Commons Work and Pensions, Business, Innovation and Skills Committees, First Report of the Work and Pensions Committee and Fourth Report of the Business, Innovation and Skills Committee of Session 201617 (July 2016) at p3.

${ }^{52}$ Above at ch4.

53 'Ex-BHS boss Dominic Chappell faces directorship ban' (BBCNews, 27 March 2018) at https://www.bbc.co.uk/news/business-43555259

${ }^{54}$ House of Commons Work and Pensions, Business, Innovation and Skills Committees, First Report of the Work and Pensions Committee and Fourth Report of the Business, Innovation and Skills Committee of Session 201617 (July 2016) at p4.

${ }^{55}$ The agency problem is discussed in the classic work M Jensen and W Meckling, "Theory of the Firm: Managerial Behavior, Agency Costs and Ownership Structure" (1976) 3 Journal of Financial Economics 305. The primacy of shareholders as principals and residual claimants is well-accepted in the UK, see John Armour, Simon Deakin and Suzanne J. Konzelmann, 'Shareholder Primacy and the Trajectory of UK Corporate Governance' (2003) at http://www.cbr.cam.ac.uk/fileadmin/user upload/centre-for-businessresearch/downloads/working-papers/wp266.pdf; Andrew Keay and Rodoula Adamopoulou, 'Shareholder Value and UK Companies: A Positivist Inquiry' (2012) European Business Organisation Law Review 1.
} 
suppliers and customers with a strong and legitimate interest in the way a company is run. ${ }^{56}$ The government's approach arguably marked a significant development in corporate governance policy.

Corporate governance policy in the UK has been centred upon publicly listed companies and their dispersed (mainly institutional) shareholder community. The fall of $\mathrm{BCCl}$ and Polly Peck due to management fraud in 1991 triggered a thorough examination of honest financial reporting by companies and Sir Adrian Cadbury was asked to lead a committee to look into that issue. The Cadbury committee however rightly identified that the governance of the company was integral to a sound financial reporting process. The Cadbury Report ${ }^{57}$ dealt with a model of good governance for publicly-listed companies and this culminated in the Cadbury Code of Corporate Governance, the pioneering piece of soft law on corporate governance in the UK. Although the very first Corporate Governance Code in the UK addressed shareholders' damaged interests from corporate financial scandals, the Code was subsequently influenced by a mixture of concerns some of which had a social flavour, such as the outcry in 1995 regarding excessive executive pay at utilities companies at a time of social discontent over high living costs, ${ }^{58}$ the response to the global financial crisis $2007-9,{ }^{59}$ and more recently the need to engage more with employee welfare and concerns. ${ }^{60}$

However, although the Corporate Governance Code covers matters beyond shareholders' interests, the approach consistently adopted in corporate governance policy is that shareholders should be the ones to monitor companies in their adherence to the Code. Shareholders are regarded to have 'enlightened' self-interest ${ }^{61}$ as investors of companies, and presumed to care not just for companies' financial performance, but also for wider issues like risk management, stakeholder and social relations. ${ }^{62}$ In this manner, it can be queried how corporate governance policy can be extended to large private companies after the BHS scandal. Many large private companies are closely-held or have significant shareholders, perhaps to protect such companies from market pressures and to ensure founders', families' and large owners' (such as private equity funds) interests are met in controlling and managing the companies. The governance problems identified in relation to BHS rightly related to controlling shareholders' greed and extraction, so the model of relying on shareholders to check on managerial decisions is arguably not applicable. Many governance problems at large private companies relate to protecting stakeholders' interests, and in BHS' case, being a formerly listed company meant that it had the legacy of significant stakeholder footprint. In

\footnotetext{
${ }^{56}$ BEIS, Corporate Governance Reform: The Government's Response to the Green Paper for Consultation (Aug 2017) at para 3.1, p36.

${ }^{57}$ Adrian Cadbury, Report of the Committee on the Financial Aspects of Corporate Governance (Dec 1992).

${ }^{58}$ Paras 1.6-1.7, Richard Greenbury, Report: Directors' Remuneration (17 Jul 1995).

59 David Walker, Review of Corporate Governance in Banks and Financial Institutions (Nov 2009), subsequently inspiring the Institutional Shareholder Committees's principles of stewardship which led to the Financial Reporting Council's adoption of a Stewardship Code for institutional investors in 2010 to encourage constructive engagement and monitoring of investee companies.

60 The Corporate Governance Code 2018 now requires Boards to engage with employee voice, Provision 5 . This is against a backdrop of the continued disempowerment of employees and scandals regarding employment conditions, such as the Parliament Inquiry into SportsDirect, see House of Commons Business Innovation and Skills Committee, Employment Practices at SportsDirect (2016-7) at https://publications.parliament.uk/pa/cm201617/cmselect/cmbis/219/219.pdf.

61 'Enlightened shareholder value' posited by policy-makers in discussions leading to reform in the UK Companies Act 2006, Andrew Keay, The Enlightened Shareholder Value Principle and Corporate Governance (Oxford: Routledge, 2012); Richard Williams, 'Enlightened Shareholder Value in UK Company Law' (2012) 35 UNSW Law Journal 360.

62 UK Stewardship Code, also see discussion in Iris H-Y Chiu, 'Turning Institutional Investors into "Stewards"Exploring the Meaning and Objectives of "Stewardship"' (2013) Current Legal Problems 1.
} 
addressing large private companies' corporate governance, the government's reforms signal the introduction of new tenets to corporate governance policy, i.e relating good governance in companies not only to shareholders' private interests (with hope in their wider 'representative' capacity) but also to public and social interests. ${ }^{63}$ The growing linkage between corporate governance and the fulfilment of broader social issues is also reflected in trends favouring ESG (Environmental, Social and Governance) investing, impact investing and sustainable financing initiatives by major institutional investors and policy makers. ${ }^{64}$ We therefore posit that the Wates Principles reflects an intended change in government policy regarding the nature and norms of corporate governance towards responsible business-society relations. ${ }^{65}$ The Principles have also been fashioned in collaboration between business, policy-makers, professions and stakeholders. ${ }^{66}$

\section{The Social Contract Theory Framework}

As business-society relations is the crucial context that underpins the need to examine the corporate governance of large private companies in the UK, we posit that an appropriate theoretical framework for the Wates Principles is that of social contract theory, instead of the agency-based theoretical framework applicable to dispersed publicly traded companies. This Section sets out the theoretical framework.

The social contract theory of business-society relations applies the political construct of the social contract ${ }^{67}$ to business organisations. Wempe posits that it is the most optimal theoretical construct yet for the framing of business-society relations. ${ }^{68}$ Donaldson first applied the social contract to business-society relations, ${ }^{69}$ and this theoretical construct has been refined into a much more rounded and robust framework. ${ }^{70}$ The social contract is capable of dealing with explaining why society permits productive economic organisations to be formed, ${ }^{71}$ as well as how such productive economic organisations should relate to society. ${ }^{72}$ Although one may instinctively draw an alignment between the social contract theory with the contractarian theory of the firm (to be discussed shortly), we posit that it is compatible with the contractarian nature of the firm (the 'micro'-based theory), the communitarian theory of the firm (the 'macro'-based theory) and the political theory of the firm (based on power, and expounded by some theorists on corporations' social citizenship, discussed below). The social contract theory of business organisations arguably has universal applicability to all forms of business, including large private companies.

\footnotetext{
${ }^{63}$ BEIS, Corporate Governance Reform: Government Response to Green Paper (August 2017) at p2, and Section 2.

${ }^{64}$ An important trend which we cannot cover in this article in full. See Financial Times, 23 October 2018. "BlackRock stakes claim on 'sustainable investing' revolution"; European Commission "Sustainable Finance" website, at https://ec.europa.eu/info/business-economy-euro/banking-and-finance/sustainable-finance_en 65 The Wates Principles specifically discusses generation of value for society and minimising business harms to society, see Introduction, Wates Principles (2018) at https://www.wates.co.uk/who-we-are/wates-principles/. ${ }^{66}$ Wates Principles have been drafted by a Coalition group of members with different representations.

${ }^{67}$ Discussed in Thomas Donaldson, Corporations and Morality (Prentice Hall 1982) ch 3 as based on Western political thought such as the Lockean model of justifying government as a necessary moderation to individual liberty in order to preserve social order.

${ }^{68}$ Ben Wempe, 'In Defense of a Self-disciplined, Domain-specific Social Contract Theory for Business Ethics' (2005) 15 Business Ethics Quarterly 113.

69 Thomas Donaldson, Corporations and Morality (Prentice Hall 1982).

${ }^{70}$ See discussion below.

${ }^{71}$ Discussed in John Douglas Bishop, 'For-Profit Corporations in a Just Society: A Social Contract Argument Concerning the Rights and Responsibilities of Corporations' (2008) 18 Business Ethics Quarterly 191.

${ }^{72}$ The focus of Donaldson's thesis (1982), above.
} 
Donaldson ${ }^{73}$ offered a social contract theory of 'productive organisations' in order to advance his argument that productive organisations abide by a social contract encompassing business ethics, refuting the Friedman thesis that corporations' sole social responsibility is to maximise the profits of stockholders. Crucially, Donaldson argued that in a 'state of nature' where no productive organisations existed and that productive activity would by default be carried out alone, people would make hypothetical bargains to be able to organise productivity in a collective form in order to exponentially benefit from productive efficiencies, consumption and the organisation of human capital. He argued that the hypothetical bargain that society would make with business included terms to benefit and not harm consumers and employees, consistent with fundamental notions of liberty and justice. Hence, business-society relations can be framed as a social contract, which is consistent with an individualistic libertarian view of economic organisation, connecting political and social notions of justice with the micro- economic conception of the business organisation. ${ }^{74}$ This articulation of the social contract based on a hypothetical bargain resonates with the contractarian theory of the firm first depicted by Coase, ${ }^{75}$ but is able to capture private and social interests within its construct. The contractarian theory of the firm is confined only to private interests as it looks at the firm as an umbrella of individual transactions that are more efficient if they become relational in nature. Further theoretical development then took place in relation to how the governance rules of firms should be derived, as based on hypothetical bargains made by these relational contracting parties. ${ }^{76}$

Subsequent commentators endorse that Donaldson's 'state of nature' model has advanced a viable theoretical construct for the social contract in business beyond political theory, and later models have developed thinking about hypothetical bargains made between business and society from the perspective of individuals behind a 'veil of ignorance ${ }^{\prime 77}$ so that they are unaware of their own attributes and resources, in order to consider how they may bargain impartially for a set of norms to govern the establishment of productive organisations and their relations with society.

As Bishop ${ }^{78}$ and Hsieh ${ }^{79}$ point out, this thesis, which is based on the hypothetical individual will as the micro-constituent of society, justifies the formation of business organisations, but it is more arguable that certain ethical norms argued for by Donaldson would necessarily emanate from the

\footnotetext{
73 Thomas Donaldson, Corporations and Morality (Prentice Hall 1982), ch3.

${ }^{74}$ The economic conception of the corporation is based on a micro perspective of explaining a firm as a nexus of contracts between individuals that wish to carry out productive activity on a sustained and continuing basis, therefore preferring organisation to constant market exchanges. Hence the firm is essentially 'contractarian' in nature, see Ronald Coase, "The Nature of the Firm" (1937) 4 Economica 386-405.

${ }^{75}$ Above.

${ }^{76}$ Armen A Alchian and Harold Demsetz, “Production, Information Costs and Economic Organisation" (1972) 62 The American Economic Rev 777, Oliver Williamson, “Corporate Governance" (1984) 93 Yale Law Journal 1197; Frank H Easterbrook and Daniel R Fischel, "The Corporate Contract" in The Economic Structure of Corporate Law (Cambridge Mass: Harvard University Press 1991) at $1 \mathrm{ff.}$

77 The Rawlsian model, see Ben Wempe, 'In Defense of a Self-disciplined, Domain-specific Social Contract Theory for Business Ethics' (2005) 15 Business Ethics Quarterly 113; Dieter Zinnbauer, 'Getting Serious about Corporate Citizenship' (2013) at https://papers.ssrn.com/sol3/papers.cfm?abstract id=2349616; John Douglas Bishop, 'For-Profit Corporations in a Just Society: A Social Contract Argument Concerning the Rights and Responsibilities of Corporations' (2008) 18 Business Ethics Quarterly 191; Edward J Conry, 'A Critique of Social Contract Theory for Businesses' (1995) 5 Business Ethics Quarterly 187; Paul Neiman, 'A Social Contract for International Business Ethics' (2013) 114 Journal of Business Ethics 75.

78 John Douglas Bishop, 'For-Profit Corporations in a Just Society: A Social Contract Argument Concerning the Rights and Responsibilities of Corporations' (2008) 18 Business Ethics Quarterly 191.

${ }^{79}$ Nien-hê Hsieh, 'The Social Contract Model of Corporate Purpose and Responsibility' (2016) 25 Business Ethics Quarterly 433.
} 
hypothetical social contract. ${ }^{80}$ Indeed Mansell, ${ }^{81}$ taking the same 'state of nature' assumption, argues that based on the micro-constituent of an individual's will to carry out productive activity, the social contract would be confined to the relations within the productive organisation and no fundamental norms could be derived for business-society relations.

Mansell argues that the norms that will be hypothetically bargained for would only relate to furthering the productive or 'corporate' objective, and those are in relation to property rights and rights with respect to honouring and enforcing contractual obligations. As individuals pool together capital and entrust property to the productive organisation, the productive organisation's mandate must be based on carrying out shareholders' interests and the productive organisation's purposes can only be fulfilled if the transactions it enters into are honoured and enforced. In this manner, the 'social contract' arrived at would be consistent with the contractarian theory for corporate law that focuses on private interests and Friedman's thesis. However, we see this as a highly instrumental view of the exercise of the individual's will in the 'state of nature' as it is insularly focused on individuals' economic purposes without bearing in mind theoretical completeness in relation to individuals' wills. In other words, Mansell's thesis assumes that shareholders are only economic actors and not more.

We posit that shareholders or more broadly, corporators, are not merely single-minded economic persons, and Bishop ${ }^{82}$ rightly argues that even on a utilitarian basis, they would only consent to the formation of collective productive organisations upon the basis of fundamental norms that are consistent with the maximisation of individual liberty. These are: productive organisations do not injure individuals' liberty enjoyed up to that stage, and do not negatively interfere with the political and institutional context regarded as an underlying or meta-level social contract. In particular, Bishop regards the social contract for the formation of productive organisations as necessarily incorporating the norms that productive organisations must not violate human rights and must not interfere with institutions of government distribution, such as engaging in tax avoidance. Hence Mansell's attempt to narrowly define the social contract (particularly in the context of looking at where stakeholders stand in relation to corporations) is flawed, and has also not accounted for the concession theory, which is that in addition to society accepting the formation of productive organisations, it needs to be justified why productive organisations could be regarded as separate legal personalities. The privilege, efficiencies and benefits of corporate personality that are private in nature must at the very least be consistent with Bishop's minimalist social contract between corporations and society.

In sum, we are of the view that a micro-based theory of the social contract, which is liberal in nature, yields certain minimalist terms of understanding between productive organisations and society, viz to do no harm and respect the institutional constructs of society. Although commentators disagree as to the extent this theoretical framework yields other precise norms of the social contract, ${ }^{83}$ we

\footnotetext{
${ }^{80}$ Critique by various commentators that no justification for the derivation of the specific norms regarding consumers or employees was made in Donaldson's account, see Ben Wempe, 'In Defense of a Self-disciplined, Domain-specific Social Contract Theory for Business Ethics' (2005) 15 Business Ethics Quarterly 113; discussion in Samuel F. Mansell, Capitalism, Corporations and the Social Contract: A Critique of Stakeholder Theory (Cambridge: CUP 2013) at chs 4-5.

${ }^{81}$ Samuel F. Mansell, Capitalism, Corporations and the Social Contract: A Critique of Stakeholder Theory (Cambridge: CUP 2013).

82 John Douglas Bishop, 'For-Profit Corporations in a Just Society: A Social Contract Argument Concerning the Rights and Responsibilities of Corporations' (2008) 18 Business Ethics Quarterly 191.

${ }^{83}$ See $n 80$.
} 
accept that (a) a social contract theory of business-society relations is robust and (b) such a theoretical construct can be developed to yield certain fundamental terms of the social contract. Neiman ${ }^{84}$ for example employs the 'state of nature' construct with modifications tailored to a situation of a multinational corporation setting up operations in a developing economy and likely to impact on a local community's way of life. Under modified Rawlsian conditions in this hypothetical negotiation, a set of more precise terms consistent with but extended from Bishop's minimal content can be articulated.

If we adopt a more communitarian view of productive organisations, i.e we do not merely analyse their formation based on the exercise of individual will at a micro level, but rather view the individual as socially-embedded, ${ }^{85}$ then the social contract construct explains the rise of the collective productive organisation as a form of social collaboration. Kaptein and Wempe ${ }^{86}$ argue that such collaboration would proceed in an ordered manner due to both efficiency and social reciprocity, and would unlikely be a mere collection of individually-driven exchanges on the market. The social contract is the result of such collaboration and would likely contain terms that pertain to advancing common good and mutual benefits, while protecting individuals and society from harm. A communitarian view of productive organisations that incorporates social reciprocity and shared values is not inconsistent with the libertarian justifications for government and order, and would encompass self-restraint and other-regarding behaviour, including an ethical content that 'cannot reasonably be rejected' ${ }^{87}$ The communitarian view is likely to yield a richer content for the terms of the social contract, extending from minimalist content to realising common values and goals. ${ }^{88}$

Thirdly, framing business organisations as being in a social contract with society is also based on observed social footprint and impact entailing from the business' exercise of power in communities and globally. Businesses see themselves as existing within social fabric, as our brief survey of business practices shows shortly. Dunfee ${ }^{89}$ argues that business-society relations are framed in 'extant social contracts' between individual corporations and communities, for example in corporate codes of conduct, multi-stakeholder standards for corporate products or practices etc. These practically tie corporations and their communities together, even if they are likely to be soft law instruments, by express or implied consent. Implied consent can be derived from conduct or from the fact that non-consenters enjoy the instrumental value of the arrangement. These observed arrangements give rise to the inductive theory of a meta-level social contract between business and society.

More recently, such an inductive approach has inspired the framing of the social contract between business and society as 'social citizenship'. ${ }^{90}$ Social citizenship theory returns the social contract to

\footnotetext{
${ }^{84}$ Paul Neiman, 'A Social Contract for International Business Ethics' (2013) 114 Journal of Business Ethics 75.

${ }^{85}$ Discussed in Hazel Henderson, 'Transnational Corporations and Global Citizenship' (2000) 43 American Behavioral Scientist 1231.

${ }^{86}$ Muel Kaptein and Johan Wempe, 'The Corporation as Social Contract' in The Balanced Company: A Theory of Corporate Integrity (Oxford: OUP 2002).

${ }^{87}$ TM Scanlon, What We Owe to Each Other (Cambridge, MA: Harvard University Press, 1998) on arguing for an obligation of self-restraint where a burden imposed on one meets other-regarding needs and is the least burdensome of alternatives.

${ }^{88}$ For example, applying to a more specific context of current social goals, sustainability would be regarded as a common goal that can be embodied in a social contract between business and society, see E Palmer, 'Multinational Corporations and the Social Contract' (2001) 31 Journal of Business Ethics 245.

${ }^{89}$ Thomas W Dunfee, 'Business Ethics and Extant Social Contracts' (1991) 1 Business Ethics Quarterly 23.

${ }^{90}$ Social citizenship is based on the existence of a social contract, see Michael S. Aßla"nder \& Janina Curbach, 'The Corporation as Citoyen? Towards a New Understanding of Corporate Citizenship' (2014) 120 Journal of
} 
its political roots and reconciles the individualistic and libertarian view of the social contract with its essential public life. ${ }^{91}$ We suggest that the social citizenship conceptualisation is capable of reconciling the micro-based and macro-based theories of the social contract. Just as the political social contract justifies the authority of public and governmental institutions over individuals, the political social contract endows upon individuals citizenship status, rights and responsibilities within the contractual fabric, which is public and social life. Second, the conceptualisation of 'citizenship' has allowed more concrete though controversial articulation of the norms of the social contract.

The most-cited theorists of corporate citizenship, Matten et $\mathrm{al}^{92}$ advanced a conceptualisation of corporate citizenship based on corporations' legal personality, legal rights and duties ${ }^{93}$ and their increasingly significant public and social roles, including philanthropy, lobbying and for more influential corporations, providing public goods to society ${ }^{94}$ such as infrastructure and finance. Corporations are on the frontlines of shaping public interest outcomes such as the protection of human rights in supply chains and advancing sustainability agendas to protect planetary resources. In this manner, they are performing near-substitute roles for what would presumably be governmental roles, or at least in a collaborative manner with the public sector. ${ }^{95}$

Based on the practice of citizenship, the terms of business-society relations can be more precisely articulated. 'Corporate citizenship' provides the framework for articulating a range of norms that are substantive as well as procedural. We treat substantive norms as those that specify precise conduct or outcomes, and 'procedural' norms as meaning those that facilitate participation and decisionmaking on yet-to-be-determined outcomes. ${ }^{96}$ The development of 'corporate citizenship' in some commentators' views is able to transcend the somewhat discredited business-led notion of corporate social responsibility which tends to dictate business understanding to the social sphere rather than advance a form of social 'moderation' for business. ${ }^{97}$

In relation to 'substantive' norms, our literature survey yields the following findings. Donaldson and Dunfee suggest that these include the duty to develop and fulfil obligations in connection with social structures that are efficient in achieving social goods, keeping promises and respecting human

Business Ethics 541; Ronald Jeurissen, 'Institutional Conditions of Corporate Citizenship' (2004) 53 Journal of Business Ethics 87.

${ }^{91}$ See Jeurissen (2004).

92 Andrew Crane, Dirk Matten and Jeremy Moon, Corporations and Citizenship (Cambridge: CUP 2008).

${ }^{93}$ Above at ch1 and see Elisabeth Hoff-Clausen, Øyvind Ihlen, "The Rhetorical Citizenship of Corporations in the Digital Age" (2015) 7 Corporate Social Responsibility in the Digital Age 17.

${ }^{94}$ Andrew Crane, Dirk Matten and Jeremy Moon, Corporations and Citizenship (Cambridge: CUP 2008) at chs 2-

3. Also see Peter Edward and Hugh Willmott, 'Corporate Citizenship: Rise or Demise of a Myth?' (2008) 33 The Academy of Management Review 771.

95 Michael S. Aßla“nder \& Janina Curbach, 'The Corporation as Citoyen? Towards a New Understanding of Corporate Citizenship' (2014) 120 Journal of Business Ethics 541.

${ }^{96}$ To be elaborated. We note Donaldson and Dunfee's thesis advocates 3 types of 'hyper' or fundamental norms and we tend to treat the first two categories as 'substantive' broadly. This is discussed below.

97 David Sadler and Stuart Lloyd, 'Neo-liberalising Corporate Social Responsibility: A Political Economy of Corporate Citizenship' (2009) 40 Geoforum 613; Jean-Pascal Gond, 'Reconsidering the Critical Corporate Social Responsibility Perspective through French Pragmatic Sociology: Subverting Corporate Do-Gooding for the Common Good?' in Grietje Baars (ed), The Corporation (Cambridge: CUP 2017); Steve Tombs, 'The Functions and Dysfunctions of Corporate Social Responsibility' in in Grietje Baars (ed), The Corporation (Cambridge: CUP 2017). 
dignity. ${ }^{98}$ Jeurissen ${ }^{99}$ discusses that the pursuits of the corporation must be consistent with adding value to society, suggesting that the private economic objectives of the corporation must be consistent with public interest and social good. Zinnbauer ${ }^{100}$ advocates that substantive norms of citizenship must include paying the dues of citizenship and obeying laws and regulations, arguably questioning the legitimacy of modern multinational corporate practices in tax avoidance and regulatory arbitrage. In more precise terms, substantive norms should relate to topical concerns of communities and globally, such as environmental protection and sustainability, ${ }^{101}$ and where business practices disadvantage society and stakeholders, norms should relate to compensating for disadvantages that occur and developing alternatives to meet those needs. ${ }^{102}$ Particular substantive norms have already been developed in international codes such as the Global Compact, multistakeholder initiatives and corporate codes, ${ }^{103}$ but reflection and review as to their credibility and

98 Thomas Donaldson and Thomas Dunfee, 'Integrative Social Contracts Theory: A Communitarian Conception of Economic Ethics' (2005) 11 Economics and Philosophy 85.

99 Jeurissen (2004).

100 Dieter Zinnbauer, 'Getting Serious about Corporate Citizenship' (2013) at https://papers.ssrn.com/sol3/papers.cfm?abstract_id=2349616.

${ }^{101}$ Kerrie L. Unsworth, Sally V. Russell and Matthew C. Davis, 'Is Dealing with Climate Change a Corporation's Responsibility? A Social Contract Perspective' (2016) 7 Frontiers in Psychology 1212.

102 Jeffrey L. Sturchio and Louis Galambos, 'Corporate Purpose and Social Responsibility' in Greg Urban (ed), Corporations and Citizenship (University of Pennsylvania Press 2014) at ch5; Karen Ho, 'Corporate Nostalgia? Managerial Capitalism from a Contemporary Perspective' in Greg Urban (ed), Corporations and Citizenship (University of Pennsylvania Press 2014) at ch 15 both discussing how global competitive pressures have changed corporations' levels of social contribution, and in particular in Ho, how downsizing has entailed adverse social ramifications for social mobility.

103 Dunfee's 'extant' social contracts thesis (1991), also Naomi A. Gardberg and Charles J. Fombrun, 'Corporate Citizenship: Creating Intangible Assets across Institutional Environments' (2006) 31 Academy of Management Review 329; many chapters in Ingo Pies and Peter Koslowski (eds), Corporate Citizenship and New Governance (Heidelberg: Springer 2011); Tim Büthe, ' Private Regulation in the Global Economy: A (P)review' (2010) 12 Business and Politics 1; Larry Catá Backer, 'Governance Polycentrism--Hierarchy and Order Without Government in Business and Human Rights Regulation' (2014) at http://ssrn.com/abstract=2373734; Larry Catá Backer, 'Theorizing Regulatory Governance Within its Ecology: The Structure of Management in an Age of Globalization' (2016) at https://ssrn.com/abstract=2783018; Larry Cata Backer, 'A Lex Mercatoria for Corporate Social Responsibility Codes Without the State? A Critique of Legalization Within the State Under the Premises of Globalization' (2017) 24 Indiana Journal of Global Legal Studies 115; Larry Cata Backer, 'Global Panopticism: States, Corporations, and the Governance Effects of Monitoring Regimes' (2008) 15 Indiana Journal of Global Legal Studies 101; Neil Walker and Gráinne de Búrca, 'Reconceiving Law and New Governance' (2007) at http://ssrn.com/abstract=987180; Peer Zumbansen, 'Transnational Legal Pluralism' (2010) 1 Transnat'l Legal Theory 141.

Particular developments, eg Jette Knudsen, 'The Growth of Private Regulation of Labor Standards in Global Supply Chains: Mission Impossible for Western Small- and Medium-Sized Firms?' (2013) 117 Journal of Business Ethics 387; Patrick Haack, Dennis Schoenborn and Christopher Wickert, 'Exploring the Constitutive Conditions for a Self-Energizing Effect of CSR Standards: The Case of the "Equator Principles"' (October 2010) University of Zurich Institute of Organization and Administrative Science IOU Working Paper No 115 http://papers.ssrn.com/sol3/papers.cfm?abstract id=1706267.

For programs of third party certification and monitoring such as SA8000, the Ethical Trading Initiative, the Marine and Forest Stewardship Councils initiatives, the ISO14000 for environmental management etc, many of which have attained credibility due to independent monitoring, see Karen Bradshaw Schulz, 'New Governance and Industry Culture' (2013) 88 Notre Dame L. Rev. 2515; Kees Bastmeijer and Jonathan Verschuuren, 'NGOBusiness Collaborations and the Law: Sustainability, Limitations of the Law, and the Changing Relationship Between Companies and NGOs', in: Istemi Demirag (Ed.), Corporate Social Responsibility, Accountability and Governance. Global Perspectives (Greenleaf Publishing, Sheffield, 2005), pp. 314-329; Dara O'Rourke, 'Outsourcing Regulation: Analyzing Nongovernmental Systems of Labor Standards and Monitoring' (2003) 31 Policy Studies Journal 1; David Wirth, 'The International Organization for Standardization: Private Voluntary 
robustness should be constantly made, with reference to fundamental deontological frames such as ethics and morality. ${ }^{104}$ Further, although Scherer and Palazzo ${ }^{105}$ eschew the use of the term 'citizenship' and prefer the term 'corporations' political social responsibility' as responsibility indicates a more imperative nature, they advocate for corporate responsibilities to provide public goods, consistent with corporations' influence and footprint, such as where multinational corporations operate in developing countries with limited institutions and infrastructure. ${ }^{106}$ They envisage corporate responsibilities to address issues like disease, malnutrition, homelessness, environmental degradation etc, within a framework of deliberative democracy. ${ }^{107}$ This brings us to the more 'procedural' norms that flow from a 'citizenship' conceptualisation of corporations.

Commentators overwhelmingly agree that corporations must participate in broader social engagement and accountability, so as to facilitate negotiations for micro social contracts, ${ }^{108}$ which would contain particular norms on corporations' relations with the communities they affect or operate in. Such engagement includes two-way engagement, ${ }^{109}$ genuine endeavours to discern social expectations by corporations, ${ }^{110}$ constructing understanding of issues jointly and in an integrated business-society manner, ${ }^{111}$ accounting for managerial decision-making, ${ }^{112}$ being accountable for implementation, review and outcomes of socially-facing initiatives, ${ }^{113}$ and preparedness to enter into new terms of the social contract where conditions change and new social demands arise. ${ }^{114}$

Standards as Swords and Shields' (2009) 36 Boston College Environmental Affairs Law Review 79; Aseem Prakash, The Voluntary Environmentalists (Cambridge: CUP 2009)

${ }^{104}$ Edwin M Epstein, 'Business Ethics, Corporate Good Citizenship and the Corporate Social Policy Process: A View from the United States' (1989) 8 Journal of Business Ethics 583; Steve Mackey, 'Virtue Ethics, CSR and Corporate Citizenship' (2014) 18 Journal of Communication Management 131 and the values of trust ie integrity, beneficence and competence as advocated by Oliver F Williams, 'Responsible Corporate Citizenship and the Ideals of the United Nations Global Compact' in Oliver F Williams (ed), Peace through Commerce (University of Notre Dame Press 2008) at ch21.

105 Georg Scherer and Guido Palazzo, 'Toward a Political Conception of Corporate Responsibility: Business and Society Seen from a Habermasian Perspective' (2007) 32 Academy of Management Review 1096.

${ }^{106}$ Georg Scherer and Guido Palazzo, 'The New Political Role of Business in a Globalized World: A Review of a New Perspective on CSR and its Implications for the Firm, Governance, and Democracy' (2011) 48 Journal of Management Studies 899.

107 Scherer and Palazzo (2007) above.

108 Donaldson and Dunfee (2005) above.

${ }^{109}$ Zinnbauer (2013), above, Dorothe'e Baumann-Pauly \& Andreas Georg Scherer, 'The Organizational Implementation of Corporate Citizenship: An Assessment Tool and its Application at UN Global Compact Participants' (2013) 117 Journal of Business Ethics 1.

${ }^{110}$ Mark Glazebrook, 'The Social Construction of Corporate Citizenship' (2005) 17 Journal of Corporate Citizenship 53.

${ }^{111}$ Glen Whelan, Jeremy Moon and Bettina Grant, 'Corporations and Citizenship Arenas in the Age of Social Media' (2013) 118 Journal of Business Ethics 777.

112 Jeffrey Smith, 'Corporate Social Purpose and the Task of Management' in Greg Urban (ed), Corporations and Citizenship (University of Pennsylvania Press 2014) at ch4.

113 Baumann-Pauly and Scherer (2013) above.

${ }^{114}$ Marilise Smurthwaite, 'The Purpose of the Corporation' in Oliver F Williams (ed), Peace through Commerce (University of Notre Dame Press 2008) at ch1; Wesley Cragg, 'Human Rights and Business Ethics: Fashioning a New Social Contract' (2000) 27 Journal of Business Ethics 205. 
In practice, the rise of 'extant' social contracts ${ }^{115}$ in terms of industry-led, multi-stakeholder or international organisation-led initiatives has been an indefatigable trend, ${ }^{116}$ such that it is practically difficult to deny the social contract theory of business-society relations even if arguments continue to be developed at theoretical levels. ${ }^{117}$ These have also tended to apply universally to all business, so that the public-private company divide in characterisation is less important. ${ }^{118}$ Although commentators may be sceptical of the enforceability of soft law, and the embodiment of their terms as social contracts, ${ }^{119}$ non-legal 'ties' are not practically ineffective, ${ }^{120}$ and arguments have indeed been developed to make social contracts legally enforceable. ${ }^{121}$ The Dutch have also introduced the practice of covenants entered into by the government, industry and stakeholders, which may advance the potential of legal enforceability. ${ }^{122}$ Further, the adoption by corporate regulation of some of the norms that have hitherto been embodied in social contracts ${ }^{123}$ signals shifts in the uncertain landscape of business-society relations. In sum, we argue that the grounding of large private companies' relations with society in the theoretical construct of the social contract is justified, and the intellectual development of the norms of such social contracts is relatively advanced and continues to mature. Indeed Beckers argues that corporate social responsibility statements made by companies could be regarded as 'contractually binding' in law and ought to be enforceable in private law. ${ }^{124}$ Nevertheless, despite the questionable nature of legal enforceability, practical commitment and enforceability are not elusive for many extant social contracts. In this light, we move on to construct the terms of the social contract between large private companies in the UK and society. We seek in the next Section to derive the norms of such a contract as a set of benchmark norms, against which to evaluate the achievements of the Wates Principles.

\section{Analysing the Wates Principles as Terms of Social Contract}

In order to examine the Wates Principles as a set of terms for the social contract between large private companies and society, we first derive a set of benchmark norms for large private companies

\footnotetext{
115 Dunfee (1991) above.

${ }^{116}$ See n103.

${ }^{117}$ Ann Florini, 'Global Companies and Global Society: The Evolving Social Contract' in John Mikler (ed), The Handbook of Global Companies (Chicester: John Wiley \& Sons 2013) at ch20; Kate MacDonald, 'The Socially Embedded Corporation' in John Mikler (ed), The Handbook of Global Companies (Chicester: John Wiley \& Sons 2013) at ch22; empirical research on the impact of social demand on corporate practice, see Cristel Antonia Russell, Dale W Russell and Heather Honea, 'Corporate Social Responsibility Failures: How Do Consumers Respond to Violations of Implied Social Contracts?' (2016) 136 Journal of Business Ethics 759; George A. Shinkle and J. William Spencer, 'The Social Construction of Global Corporate Citizenship: Sustainability Reports of Automotive Corporations' (2012) 47 Journal of World Business 123.

${ }^{118}$ Glen Whelan, Jeremy Moon and Bettina Grant, 'Corporations and Citizenship Arenas in the Age of Social Media' (2013) 118 Journal of Business Ethics 777 on the role of social media in flattening social access to business generally, Lynn Sharp Paine, 'Corporate Power and the Public Good' in Greg Urban (ed), Corporations and Citizenship (University of Pennsylvania Press 2014) at ch2; Daniel Malan, 'From Being Apart to Being Partners' in Oliver F Williams (ed), Peace through Commerce (University of Notre Dame Press 2008) at ch17. ${ }^{119}$ Dinah Rajak, 'Let Business Lift Africa out of Poverty' in In Good Company: An Anatomy of Corporate Social Responsibility (Stanford University Press 2011).

120 See n103.

${ }^{121}$ Anna Beckers, 'Regulating Corporate Regulators through Contract Law? The Case of Corporate Social Responsibility Codes of Conduct' (2016) at http://ssrn.com/abstract=2789360; Enforcing Corporate Social Responsibility Codes: On Global Self-Regulation and National Private Law (Oxford: Hart Publishing, 2015).

122 See https://www.imvoconvenanten.nl/.

${ }^{123}$ Discussed critically in Iris H-Y Chiu, 'An Institutional Theory of Corporate Regulation' (2018) Current Legal

Problems at https://doi.org/10.1093/clp/cuy006.

124 Beckers (2015) and (2016), above.
} 
based on the theoretical framework discussed above. These may be regarded as 'hypothetical' contractual terms in the contractarian paradigm but we suggest they equally reflect social expectations of large private companies within a communitarian paradigm of the company as discussed above.

\section{Deriving Benchmark Norms}

In seeking a set of benchmark norms, we first adopt the 'state of nature' model that Donaldson adopted for the social contract analysis of business-society relations, and adapt it for the large private company. We imagine a starting scenario behind a Rawlsian veil of ignorance where a group of individuals wish to engage in collective productive activity but with explicit preferences for a private company. We take our approach after Neiman ${ }^{125}$ when he considered how the terms of a social contract can be developed more specifically between a multinational corporation and a local community of a developing country that the corporation would be operating in. We suggest that the modified conditions for the large private company would be that the individuals know that they know each other, wish to keep the means of production under control, by restricting the provision of finance and other capital amongst themselves (viz 'private preferences'), but are not opposed to or indeed are interested in growth of the company's productive capacity. How would a hypothetical contract be struck with society in relation to such a company's business-society relations?

As the corporators of the purported large private company and society are equally behind a veil of ignorance, no one knows the real extent of resources the group of individuals has, the extent of market demand for the output of the organisation and the prospects for growth and influence. This means that society is also unable to tell the relative resourcefulness of the group of individuals and those outside the group, what products or services are to be offered, and the desirability of the organisation's expansion. Under these conditions, we suggest that both the company and society would agree to the formation of the company and the acceptance of the incorporators' private preferences, if the company's creation and enjoyment of private wealth does not damage any other's rights and liberties. ${ }^{126}$ This hypothetical bargain would hold if both the company and society assume the lowest possible extent of interface between the company and society ie that the company's scale of production and market profile are modest and that it keeps its means of production and management private, involving as little outside the circle of incorporators as possible. This position is consistent with the utilitarian support for maximum individual liberty.

However, moving away from the lowest possible extent of interface between the company and society, where the company co-opts more of society to help in generating economic productivity, for example by employment, using suppliers and sourcing for finance beyond the private circle, such as by borrowing, then we suggest the company and society would introduce the following terms in their social contract in order that both the company and society benefit from the company's interface with society, and that company's private preferences may have to be adjusted. In other words, we propose that key to the hypothetical social contract would be a negotiated and appropriate level of self-restraint on the part of the company in furthering its private preferences to the hilt, in order to attain a balance of mutual benefit to company and society, and to prevent harm to any other's rights and liberties. The distributive aspects of the social contract, in addition to the libertarian, are necessary in social relations of co-production and dependence, and consistent with the Rawlsian principle of social justice that social and economic inequalities should only persist under conditions of opportunity that provide the greatest amount of benefit to the least

\footnotetext{
${ }^{125}$ Neiman (2013) above.

${ }^{126}$ Consistent with Bishop's minimal content (2008).
} 
advantaged. Society should recognise the benefits of private preferences, as empirical research confirms that controlling interests ${ }^{127}$ often look after the company and its long-term success. ${ }^{128}$ However, empirical evidence also highlights the incentives of these shareholders to extract private benefits or even to misappropriate wealth in an unchallenged manner. ${ }^{129}$ Hence, the hypothetical social contract between large private companies and society would necessarily incorporate the possible moderation of private preferences in order to be aligned with the fundamental principles of preventing harm and advancing mutual benefit set out above.

We propose a further distillation of benchmark substantive norms in (a) and procedural norms in (b) below to achieve a negotiated and appropriate level of self-restraint for the company's private preferences. (a) contains our proposals for a balance in 'mutual benefit' to the company and society while not being overly prescriptive and allowing for specific negotiated arrangements (Donaldson and Dunfee's micro social contracts, see above). (a) also refers to the company's responsibilities to prevent harm. (b) provides for a facilitative and procedural framework that will allow specific arrangements to be made and reviewed between the company and society.

(a) The company and society must engage on fair terms ${ }^{130}$ in relation to the company's enjoyment of private preferences and wealth, in particular

a. The pursuit of private preferences reasonably takes into account of society's contribution to the productive process, and is supportive of the sustainability of such contribution. For example, where the company benefits from suppliers' specialised expertise, the supply contracts should be on fair terms such as no undue delay in payment terms. ${ }^{131}$ Where the company benefits from recruiting skilled and educated employees, it should also add value to their human capital instead of causing demoralisation. ${ }^{132}$

b. The pursuit of private preferences must not be at the expense of other individuals' reasonable expectation of benefit or welfare ${ }^{133}$ or cause disproportionate disadvantage or exploitation, for example, to engage in due diligence and desist from using exploited labour in supply chains. ${ }^{134}$

\footnotetext{
${ }^{127}$ We recognise that there is a variety of these types of shareholders in large private companies, from familyowned and controlled, state-owned and controlled to being wholly owned subsidiaries and private-equity owned companies. However large private companies feature significant stakes or controlling interests and that is a running theme, as opposed to dispersed ownership.

${ }^{128}$ Some benefits that controlling shareholders bring such as long-term commitment, investment in R\&D etc are discussed in Marc Moore and Edward Walker-Arnott, 'A Fresh Look at Stock Market Short-Termism' (2014) 41(4) Journal of Law and Society.

${ }^{129}$ This is also borne out in extant practice, Eg see Say Goo and Rolf H Weber, 'The Expropriation Game: Minority Shareholders' Protection' (2003) 33 Hong Kong Law Journal 71; Hubert Shea, 'Family Firms: Controversies over Corporate Governance, Performance, and Management' (2006) at http://ssrn.com/abstract=934025.

${ }^{130}$ Consistent with Scanlon (1998), R Edward Freeman, “A Stakeholder Theory of the Modern Corporation" reproduced in Max BE Clarkson ed, The Corporation and Its Stakeholders (Univ of Toronto Press 1998) at 125. ${ }^{131}$ See BEIS' initiative the Prompt Payment Code, at http://www.promptpaymentcode.org.uk/, which followed after the collapse of Carillion plc in early 2018. It was revealed that Carillion had managed its financial appearances to the last moment by squeezing suppliers and subjecting them to long payment times. 132 Donaldson (1982) at ch3.

${ }^{133}$ According to fundamental human rights and other rights consistent with political and social institutions, this baseline is drawn from Donaldson's original proposal, above and also consistent with Bishop, above.

${ }^{134}$ See s54, Modern Slavery Act 2015.
} 
c. The pursuit of private preferences must take into account any harms, injuries or cost occasioned to others or to society as a whole in the process. This would include collective harms such as environmental damage as well as individual harms such as torts. ${ }^{135}$

d. The pursuit of private preferences must be consistent with the political, social and legal institutions of society. ${ }^{136}$

e. Society should not sabotage the company's enjoyment of private preferences subject to the processes of legitimate engagement in (b).

(b) Otherwise than in accordance with legal and regulatory institutions governing companies' relations with any groups in society, the company and groups in society may in good faith enter into negotiated arrangements. ${ }^{137}$ These negotiated arrangements may explicitly refer to the need for and extent of the company's self-restraint in pursuing its private preferences. The negotiated arrangements should be facilitated by the following frameworks:

a. Meaningful, constructive engagement between representatives of society and the company that tend towards the conditions of Habermasian deliberation. ${ }^{138}$ This means that constructive engagement should be made in an open fashion without the pre-loading of assumptions and preferences so that all parties in the engagement can attain to an objective level of dialogue and understanding with each other; ${ }^{139}$

b. The adherence by the company to conditions that facilitate self-restraint or moderation, such as in its corporate governance framework, that act as a check on the pursuit of private preferences.

Our substantive and procedural benchmark norms are consistent with the hypothetical bargaining position between large private companies and society in a Rawlsian set-up. They are also consistent with the work developed by social contract theorists discussed in the previous Section and adapt well-accepted norms of social citizenship ${ }^{140}$ to the context of large private companies. Further, we argue that extant business practices as surveyed in our brief qualitative analysis below, and the improvements made by the Wates Principles over extant business practices, are consistent with our benchmark norms. We posit that our benchmark norms indicate an optimal direction of travel in

\footnotetext{
135 Broadly agreed in Neiman (2013).

${ }^{136}$ Bishop (2008) and Zinnbauer (2016).

137 The 'micro' social contract as argued for by Donaldson and Dunfee, above.

138 Jürgen Habermas, Between Facts and Norms: Contributions to a Discourse Theory of Law and Democracy (Cambridge, Mass: MIT Press, 1996) (arguing that theories of law and democracy are built upon a theory of discourse, communication and deliberation in the manner espoused in earlier works); Jürgen Habermas, Communication and the Evolution of Society (Beacon Press, 1979) [hereinafter Habermas, Communication and the Evolution of Society] (developing a theory of communication in society that is premised on language, seeking the technical qualities of language that can achieve universal conditions for understanding); Jürgen Habermas, Moral Consciousness and Communicative Action (MIT Press, 1990) (espouses the discourse theory of ethics where ethical values in shared social understandings are developed by communication in the manner espoused in earlier works); Jürgen Habermas, The Theory of Communicative Action, Vol. 2: Lifeworld and System: A Critique of Functionalist Reason (Boston: Beacon Press, 1985) (sketching out a social system whereby social order and integration is maintained by shared understandings and values developed through communication, developed from his earlier work above).

139 Broadly agreed by most commentators as an essential tenet of corporate citizenship, see Section 1.

${ }^{140}$ By commentators, referring to our survey of literature in the previous Section.
} 
framing business-society relations and that the Wates Principles are rightly evaluated against them in the next Section.

\section{Short Qualitative Survey of Extant Business Practices}

We survey 9 large private companies' mission statements, corporate responsibility and/or mandatory statements such as the Modern Slavery Statement ${ }^{141}$ to discern extant business practices that can usefully inform our benchmark norms. ${ }^{142}$ Although this is a short survey, there are interesting indicative findings, and this may pave the way for a larger and more rigorous study for examining business practices post-Wates. The nine companies comprise three founder/familycontrolled companies Arcadia Group, McLaren Technology and Wates Construction, three private equity financed companies, New Look, Brakes Group and Debenhams, ${ }^{143}$ and three large subsidiaries of holding groups that may be listed or private, ie Virgin Atlantic, Findus and Thames Water. These represent an equal number sample of the different major types of large private companies. We look for indications of companies' perspectives of their social footprint or citizenship, and extract their notable commitments to socially responsible or responsive conduct. This methodology is consistent with Dunfee's thesis (1991). We offer some observations on the gaps between extant business practices and our benchmark norms.

\begin{tabular}{|c|c|c|}
\hline Company & $\begin{array}{l}\text { Disclosure Documents } \\
\text { Surveyed }\end{array}$ & $\begin{array}{l}\text { Significant Extant Norms } \\
\text { Extracted }\end{array}$ \\
\hline Wates Group & $\begin{array}{l}\text { Code of Conduct, Bribery Act } \\
\text { statement, Modern Slavery } \\
\text { Statement, Gender pay gap } \\
\text { report, and a variety of specific } \\
\text { policies below. } \\
\text { Specific policies on Business } \\
\text { Management, Community, } \\
\text { Data Protection, Environment, } \\
\text { Equality, diversity and } \\
\text { inclusion, Health and safety, } \\
\text { Information and data security, } \\
\text { People, Quality, Anti-slavery } \\
\text { and human trafficking and Tax } \\
\text { strategy }\end{array}$ & $\begin{array}{l}\text { General Guiding principle in } \\
\text { Code: To seek to be legally } \\
\text { compliant and beyond } \\
\text { Zero tolerance of unethical } \\
\text { norms such as bribery, fraud, } \\
\text { slavery or human trafficking in } \\
\text { group or supply chain. } \\
\text { Commitment against tax } \\
\text { avoidance. } \\
\text { 'Zero harm' policy in relation } \\
\text { to workplace injury. } \\
\text { Commitment to ensure } \\
\text { teamwork with stakeholders } \\
\text { and NGOs and society. } \\
\text { Commitment in ensuring } \\
\text { proper interests of } \\
\text { stakeholders are met eg } \\
\text { prompt payment of supply } \\
\text { chain, ethical sourcing, }\end{array}$ \\
\hline
\end{tabular}

\footnotetext{
${ }^{141}$ S54, Modern Slavery Act 2015 applies to both public and private companies having a turnover over £36 million net of taxes, as prescribed by section 2, The Modern Slavery Act 2015 (Transparency in Supply Chains) Regulations 2015.

${ }^{142}$ We note that companies' s172 and corporate governance statements under s414CZA and Schedule 7 are not yet available.

${ }^{143}$ At the time of writing in late March 2019, Debenhams' fate is uncertain as sale negotiations and talks of administration have been suggested in the media.
} 


\begin{tabular}{|c|c|c|}
\hline & & $\begin{array}{l}\text { equality and freedom from } \\
\text { bullying and harassment at } \\
\text { work. } \\
\text { Respect for people and } \\
\text { communities through } \\
\text { charitable giving and } \\
\text { engagement. } \\
\text { The above largely consonant } \\
\text { with benchmark norms (a) and } \\
\text { (b), note adherence to } \\
\text { corporate governance } \\
\text { framework in (b)b refers to } \\
\text { Wates Principles. }\end{array}$ \\
\hline McLaren Technology & $\begin{array}{l}\text { There is mention of 'business } \\
\text { ethics' and 'culture and } \\
\text { corporate citizenship' in the } \\
\text { Tax Strategy but there is no } \\
\text { Code of Conduct or Ethical } \\
\text { Code to be found publicly } \\
\text { available. } \\
\text { The published corporate social } \\
\text { responsibility disclosures } \\
\text { relate to supporting STEM } \\
\text { training for young people and } \\
\text { traineeship schemes, } \\
\text { charitable giving to } \\
\text { communities. } \\
\text { There is an environmental } \\
\text { policy. }\end{array}$ & $\begin{array}{l}\text { Sustainability in terms of } \\
\text { responsible energy and } \\
\text { resource consumption and } \\
\text { recycling. } \\
\text { Commitment to ethical tax } \\
\text { planning and against artificial } \\
\text { schemes of tax avoidance. } \\
\text { Support for relevant social or } \\
\text { community causes. } \\
\text { Above are consistent } \\
\text { somewhat but very limited in } \\
\text { relation to benchmark norms } \\
\text { (a)a-d, no mention of (b). }\end{array}$ \\
\hline Arcadia Group & $\begin{array}{l}\text { Code of Conduct, Modern } \\
\text { Slavery Statement, 'Fashion } \\
\text { Footprint' which is the } \\
\text { sustainability and } \\
\text { responsibility report }\end{array}$ & $\begin{array}{l}\text { Commitment to international, } \\
\text { legal and ethical standards in } \\
\text { employment, labour } \\
\text { conditions in supply chain (this } \\
\text { is the mainstay in Code of } \\
\text { Conduct). This is supported by } \\
\text { due diligence and audit } \\
\text { schemes to map and label risk } \\
\text { profiles of suppliers in } \\
\text { compliance with these } \\
\text { standards. } \\
\text { Mentions partnership with } \\
\text { various multistakeholder } \\
\text { initiatives to attain supply } \\
\text { chain responsibility, } \\
\text { sustainable cotton sourcing. }\end{array}$ \\
\hline
\end{tabular}




\begin{tabular}{|c|c|c|}
\hline & & $\begin{array}{l}\text { Engagement with communities } \\
\text { largely through charitable } \\
\text { giving. } \\
\text { Commitment to measuring } \\
\text { environmental footprint and } \\
\text { managing sustainability eg } \\
\text { waste management and } \\
\text { environmental responsibility. } \\
\text { Seems consistent with } \\
\text { benchmark norms (a)b and d } \\
\text { and (b) a. As Arcadia Group is } \\
\text { owned by Green's family } \\
\text { investment company which is } \\
\text { tainted by the BHS discoveries, } \\
\text { it is questioned if (a)a and (c) } \\
\text { are met. No mention of (b)b. }\end{array}$ \\
\hline Brakes Group & $\begin{array}{l}\text { Sustainability policies are } \\
\text { published on website including } \\
\text { People, Planet and Products, } \\
\text { Modern Slavery Statement. } \\
\text { Also see charitable projects } \\
\text { such as Meals and More that } \\
\text { support feeding of children } \\
\text { living in poverty. }\end{array}$ & $\begin{array}{l}\text { Commitment to treating } \\
\text { employees ethically, with care } \\
\text { and with investment. } \\
\text { Ethical sourcing including } \\
\text { being part of third-party } \\
\text { certification programmes. } \\
\text { Commitment to human rights } \\
\text { protection. } \\
\text { Commitment to sustainability } \\
\text { including reducing carbon } \\
\text { emissions, waste reductions eg } \\
\text { plastic reduction. } \\
\text { Compliance with laws such as } \\
\text { health and safety, } \\
\text { competition, anti-bribery. } \\
\text { Seems largely consistent with } \\
\text { benchmark norms (a) a-d, and } \\
\text { (b)a (multi-stakeholder } \\
\text { scheme participation), no } \\
\text { mention of (b)b although } \\
\text { leadership team information is } \\
\text { available on website. }\end{array}$ \\
\hline New Look & $\begin{array}{l}\text { Code of Business Ethics- but } \\
\text { that applies more to } \\
\text { employees in terms of their }\end{array}$ & $\begin{array}{l}\text { Compliant with laws such as } \\
\text { workers' rights and anti- } \\
\text { bribery. }\end{array}$ \\
\hline
\end{tabular}




\begin{tabular}{|c|c|c|}
\hline & $\begin{array}{l}\text { expected standards of } \\
\text { behaviour such as managing } \\
\text { conflicts of interest, as well as } \\
\text { issues such as data protection. } \\
\text { Modern Slavery statement, } \\
\text { anti-corruption statement, } \\
\text { specific policies on workers' } \\
\text { rights, carbon footprint and } \\
\text { animal testing under } \\
\text { Sustainability disclosures. }\end{array}$ & $\begin{array}{l}\text { Commitment to ensure ethical } \\
\text { supply chain sourcing and } \\
\text { conditions, accompanied by } \\
\text { detailed due diligence in } \\
\text { mapping the supply chain, } \\
\text { enforcing ethical code of } \\
\text { conduct and third party audits } \\
\text { and engaging with suppliers to } \\
\text { fix risks. } \\
\text { Commitment to secure animal } \\
\text { welfare in processes of } \\
\text { production. } \\
\text { Commitment to reduction of } \\
\text { carbon footprint in Forest and } \\
\text { Fabric Policy. } \\
\text { Participation in } \\
\text { multistakeholder initiatives in } \\
\text { relation to ethical trading and } \\
\text { supply chain sourcing and } \\
\text { management. } \\
\text { Charitable giving via New Look } \\
\text { Foundation. } \\
\text { Seems consistent with } \\
\text { benchmark norms (a) b-d, less } \\
\text { on (a)a. Broad statement on } \\
\text { being customer and employee- } \\
\text { focused, lacks detail on } \\
\text { benchmark norm (b) generally. }\end{array}$ \\
\hline Debenhams & $\begin{array}{l}\text { Published sustainability } \\
\text { policies are a Supplier Code of } \\
\text { Conduct and Ethical and } \\
\text { Environment Policy. No other } \\
\text { general Code is found. }\end{array}$ & $\begin{array}{l}\text { Commitment to legal and } \\
\text { ethical employment } \\
\text { conditions. } \\
\text { Commitment to ethical } \\
\text { sourcing, ensuring ethical and } \\
\text { humane conditions for labour } \\
\text { in supply chains including ILO } \\
\text { standards. } \\
\text { Against sourcing products in } \\
\text { breach of animal testing } \\
\text { policy, GM policy or policies } \\
\text { regarding harsh or prohibited } \\
\text { chemicals, and high levels of } \\
\text { metals. }\end{array}$ \\
\hline
\end{tabular}




\begin{tabular}{|c|c|c|}
\hline & & $\begin{array}{l}\text { Sustainability policy regarding } \\
\text { timber sourcing and waste } \\
\text { management eg recycling. } \\
\text { Ethical sourcing in relation to } \\
\text { conflict-free diamonds. } \\
\text { Seems consistent with } \\
\text { benchmark norms (a) a-d } \\
\text { above, limited in relation to } \\
\text { (b)a relating to engagement } \\
\text { with stakeholders, } \\
\text { multistakeholder initiatives or } \\
\text { communities. Except } \\
\text { charitable giving is showcased. } \\
\text { No mention of (b)b. }\end{array}$ \\
\hline $\begin{array}{l}\text { Findus, owned by Nomad } \\
\text { Foods, an NYSE listed company }\end{array}$ & $\begin{array}{l}\text { Findus produces no corporate } \\
\text { disclosure of its own, and } \\
\text { survey was based on Nomad } \\
\text { Foods' sustainability report. }\end{array}$ & $\begin{array}{l}\text { Committed to sustainable } \\
\text { sourcing in terms of fishing, } \\
\text { vegetables, and sustainable } \\
\text { waste management. } \\
\text { Committed to responsible } \\
\text { products, contributing to } \\
\text { health and nutrition to fight } \\
\text { childhood obesity. } \\
\text { Links in to UN Sustainable } \\
\text { Development goals and sets } \\
\text { targets for } 2025 \text {. } \\
\text { Seems consistent with } \\
\text { benchmark norms (a) a-d } \\
\text { although little is said about } \\
\text { adhering to various corporate } \\
\text { regulations. There is no } \\
\text { mention of benchmark norm } \\
\text { (b)a in relation to stakeholder } \\
\text { engagement and although the } \\
\text { leadership team information is } \\
\text { available, there is no explicit } \\
\text { reference to (b)b in terms of } \\
\text { holding-subsidiary } \\
\text { relationships. }\end{array}$ \\
\hline $\begin{array}{l}\text { Virgin Atlantic, 51\% owned by } \\
\text { Virgin Group (a BVI company) } \\
\text { which is wholly family-owned } \\
\text { and controlled. }\end{array}$ & $\begin{array}{l}\text { Mission Statement and } \\
\text { 'Purpose' are vague and broad. } \\
\text { Mission Statement says } \\
\text { 'Embrace the human spirit and } \\
\text { let it fly' while the Purpose of }\end{array}$ & $\begin{array}{l}\text { Committed to long-term } \\
\text { impact of business decisions } \\
\text { and investments. } \\
\text { Committed to }\end{array}$ \\
\hline
\end{tabular}




\begin{tabular}{|c|c|c|}
\hline & $\begin{array}{l}\text { the Virgin Group is 'changing } \\
\text { business for good'. } \\
\text { There are no detailed Codes or } \\
\text { sustainability disclosures on } \\
\text { the Virgin Group's website. } \\
\text { The Modern Slavery Statement } \\
\text { is vague and brief on due } \\
\text { diligence processes and } \\
\text { working with suppliers to } \\
\text { attain to an unpublished Code } \\
\text { of Conduct. } \\
\text { Virgin hosts a blog where the } \\
\text { public can post and comment } \\
\text { as long as posting and } \\
\text { commenting adheres to rules } \\
\text { on fair and proper } \\
\text { communication and use of } \\
\text { technology. Virgin subsidiary } \\
\text { companies such as Media and } \\
\text { Money have separate Codes of } \\
\text { Conduct where applicable. }\end{array}$ & $\begin{array}{l}\text { embedded and measurable } \\
\text { purposes in every Virgin } \\
\text { business aimed at securing } \\
\text { positive impacts on customers, } \\
\text { people, communities and the } \\
\text { environment. } \\
\text { Virgin Unite and its charitable } \\
\text { activities. } \\
\text { The lack of specific disclosures } \\
\text { is balanced by the highly } \\
\text { eminent reputation of Branson } \\
\text { as a visionary and responsible } \\
\text { entrepreneur. } \\
\text { Vague on benchmark norms } \\
\text { (a)a-d. } \\
\text { (b)a is largely found in } \\
\text { charitable engagement and } \\
\text { vague references to being } \\
\text { embedded in communities. } \\
\text { (b)b is engaged with to an } \\
\text { extent by transparency on } \\
\text { Virgin's offshore holding } \\
\text { profile and the ownership by } \\
\text { Branson, and transparency of } \\
\text { the leadership team. }\end{array}$ \\
\hline $\begin{array}{l}\text { Thames Water, wholly owned } \\
\text { by Kemble Water Holdings } \\
\text { Limited, and owning other } \\
\text { subsidiaries for specific } \\
\text { purposes such as finance. }\end{array}$ & $\begin{array}{l}\text { Variety of policies published } \\
\text { on website, including } \\
\text { transparency of ownership } \\
\text { structure and tax status of } \\
\text { offshore subsidiaries, } \\
\text { Sustainability Policy, Corporate } \\
\text { Responsibility Policy, Policies } \\
\text { on Environment, Biodiversity, } \\
\text { Biosecurity, Heritage, Climate } \\
\text { Change, Health and Safety, } \\
\text { Honest and Ethical Behaviour; } \\
\text { Modern Slavery statement, } \\
\text { Gender pay gap report, } \\
\text { statements on stakeholder } \\
\text { engagement, partnerships and } \\
\text { community work. }\end{array}$ & $\begin{array}{l}\text { Commitment to all relevant } \\
\text { legal compliance and } \\
\text { international standards such as } \\
\text { referenced under the specific } \\
\text { policies. } \\
\text { Commitment to core } \\
\text { sustainability in relation to } \\
\text { business ie providing water } \\
\text { and managing resources, } \\
\text { dealing with responsible } \\
\text { drainage etc. } \\
\text { Commitment to managing } \\
\text { climate change by measuring } \\
\text { and reducing carbon footprint, } \\
\text { and advancing UN Sustainable } \\
\text { Development goals. } \\
\text { Commitment to weeding out } \\
\text { slavery or human trafficking in } \\
\text { employment conditions and }\end{array}$ \\
\hline
\end{tabular}




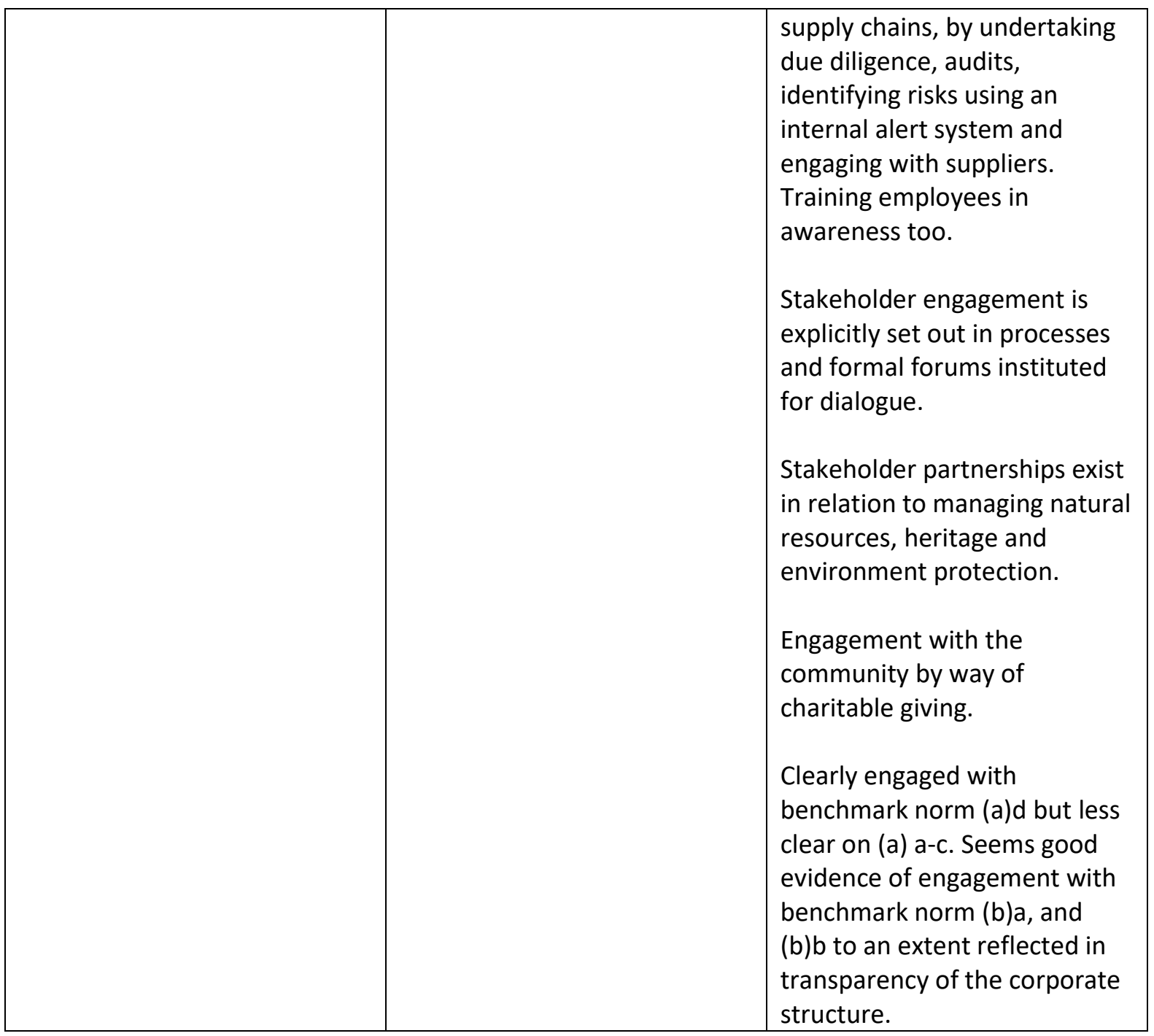

The disclosures of large private companies vary to a significant extent in shedding light on their perspectives of corporate citizenship. We can however find some common themes. There is recognition that large private companies are embedded in society and produce social impact, and we see recognition that companies wish to be compliant with and going beyond the law. Extant business practices arguably align with our benchmark norms (a)b-d in relation to prevention of harm, restraint in creating disadvantage and compliance with legal and regulatory institutions. Companies are generally less clear on benchmark norm (a). For example Wates and Brakes discuss mutual benefit to stakeholders such as suppliers and employees, and Wates. These is a lack of consistency and detail in terms of how companies demonstrate their 'other-regarding' ethos in the creation of mutual benefit in business. We also observe consistent alignment with benchmark norm (b)a as large private companies recognise the need to engage with stakeholders even if there is no formal legal impetus. In sectors where clear abuses have been identified such as in the supply chains of retail companies, or the environmental impact of a utilities company, there is clear engagement with laws, international and multi-stakeholder standards and with stakeholders to address issues. However, stakeholder-engagement seems selective and may be dominated by the company. Only Virgin welcomes two-way conversations and Thames Water explicitly discusses how such conversations will be treated. 
All companies surveyed seem to regard participating in charitable giving as their headline form of community citizenship. A concern can be raised as to whether companies perceive charitable giving as a peripheral form of business-society relations that are not connected to the 'real' business of the company. Extant business practices are especially weak in being aligned with benchmark norm (b)b, as there is little reporting of how 'private preferences' are pursued and managed, but a few companies are transparent on their ownership structures (Wates, Thames Water, Virgin).

In sum, large private companies seem to recognise their social embeddedness and do not wish to be seen as disengaged, non-compliant or irresponsible, but their engagement with citizenship varies and there is a lack of voluntary practice in demonstrating self-restraint in private preferences. On the whole we posit that our benchmark norms are supported theoretically and recognised at least implicitly by extant business practices. In particular, the lack of voluntary practice in relation to benchmark norm (b)b is one aspect where the Wates Principles has shone light and taken leadership to address. We turn next to evaluate the Wates Principles against our benchmark norms.

\section{Evaluating the Wates Principles}

As the Wates Principles is a set of best practices in relation to corporate governance, we evaluate them chiefly against the procedural benchmark norms in (b). We also discuss whether they are likely to support any of the substantive benchmark norms in (a).

\section{Quality of Principles Relating to Engagement with Society}

First, we evaluate if the Wates Principles attain a level of meaningful and constructive engagement with society towards a Habermasian deliberative model, pitched against the benchmark norm in (b)a. This model envisages a framework for discourse that is achieved at an objective, truthful and rational level. The Habermasian discourse is built upon the sharing of facts, the rational communication of knowledge without bias of political or partisan position, and inclusive two-way discussions which results in a mutual understanding and achievement of consensus. ${ }^{144} \mathrm{We}$ acknowledge this is an ideal framework hence its 'benchmark' position.

Society is outside of the corporate democracy system, ${ }^{145}$ there are no formal channels for stakeholders to be heard except on a voluntary basis. Stakeholders could, like Greenpeace, purchase shares in companies they are concerned about in order to participate as shareholders. ${ }^{146}$ Over the years, stakeholders have also formed formal and informal groups, and some of them have become vocal and influential. For example, influential non-governmental organisations (NGOs) ${ }^{147}$ can be

\footnotetext{
$144 \mathrm{~J}$ Habermas, The Theory of Communicative Action: Vol 1, Lifeworld and System: A: Critique of Functionalist Reason (Boston, Beacon Press, 1984 and 1987); Communication and the Evolution of Society (Boston, Beacon Press, 1979); Moral Consciousness and Communicative Action (Cambridge, MA, MIT Press, 1990); Justification and Application: Remarks on Discourse Ethics (Cambridge, MA, NT Press,1993), Between Facts and Norrms: Contributions to a Discourse Theory of Law and Democracy (Cambridge, Polity Press, 1996). This model is endorsed by a number of social contract theorists discussed above.

${ }^{145}$ Company law provides decision-making rights to the organs of a company defined as the Board and the General Meeting of Shareholders, see Arts 3, 4 Model Articles of Private Companies Limited by Shares, case law such as Breckland Group Holdings Ltd v London \& Suffolk Properties Ltd [1989] BCLC 100; and discussions on division of powers in leading texts, eg chs 14, 15, Davies and Worthington, Gower and Davies' Principles of Modern Company Law (London: Sweet \& Maxwell 2012).

146 'Netherlands: Greenpeace buys Shell stock' (2000) at https://corpwatch.org/article/netherlandsgreenpeace-buys-shell-stock.

147 Jonathan P. Doh and Terrence R. Guay, 'Globalization and Corporate Social Responsibility: How NonGovernmental Organizations Influence Labor and Environmental Codes of Conduct' (2004) 44 Management International Review 7; Dorothea Baur and Guido Palazzo, 'The Moral Legitimacy of NGOs as Partners of
} 
openly hostile and critical, ${ }^{148}$ while some offer companies the opportunities to be audited or certified so as to create constructive partnerships, ${ }^{149}$ while some influence supranational organisations which play an important role in shaping ethical business norms. ${ }^{150}$ Corporations have also nurtured industry associations ${ }^{151}$ to engage with stakeholders and soft law. The landscape of corporate-society relations is varied and complex.

The Wates Principles acknowledges the importance of business-society relations by explicitly referring to stakeholder engagement:

1. Stakeholders contribute tangible and intangible value to the company and play a part in its long-term success (Principles 4, 6)

2. The business could entail risks to stakeholders which should be identified and appropriately managed. (Principle 4)

These are healthy starting points, aligned with benchmark norms in (a)a-c. These Principles further support the legal requirement for directors in producing a s172 Statement which discusses how directors have taken into account employees', suppliers', customers', communities' interests and impact on the environment in business conduct. ${ }^{152}$ UK company law recognises companies as being embedded within a wider stakeholder framework than its formal decision-making systems that involve only shareholders and the Board. ${ }^{153}$ The Wates Principles affirms this and provides focused guidance to Boards in assessing stakeholders' contribution to value and risks to them. These usefully form the basis for groups in society/stakeholders to negotiate micro social contracts in Donaldson's and Dunfee's terms.

There is also specific reference to ensuring that levels of executive remuneration are set with sensitive regard for pay conditions in the company and the state of the gender pay gap (Principle 5). This is good exhortation but stops short of advancing a clearer 'mutual benefit' norm for business and society in the spirit of the benchmark norm in (a)a. We wonder if the Principles can be more positive in terms of advancing the appropriate welfare and compensation for relevant stakeholders, ${ }^{154}$ when companies create wealth and are profitable. The freedom of companies to designate pay packages is often regarded as essential contractual freedom. Such freedom, in accordance with the benchmark norms above, should be moderated by appropriate self-restraint in the pursuit of private preferences when embedded in a framework of business-society relations.

Corporations' (2011) 21 Business Ethics Quarterly 579; Heiko Spitzeck, 'Organizational Moral Learning: What, If Anything, Do Corporations Learn from NGO Critique?' (2009) 88 Journal of Business Ethics 157; Ulf Henning Richter, 'Drivers of Change: A Multiple-Case Study on the Process of Institutionalization of Corporate Responsibility Among Three Multinational Companies' (2011) 102 Journal of Business Ethics 261.

${ }^{148}$ Eg Clean Clothes Campaign ,' BSCl 10th Anniversary Shame over Rana Plaza' at https://cleanclothes.org/news/2013/06/25/bsci-10th-anniversary-shame-over-rana-plaza.

149 See n103.

${ }^{150}$ For example the OECD's principles for multinational enterprises and state-owned enterprises, the UN Global Compact and more recently the UN Guiding Principles for Business and Human Rights. See discussions Lawrence Tshuma, 'Hierarchies and Government versus Networks and Governance: Competing Regulatory Paradigms in Global Economic Regulation' (2000) 9 Soc. \& Legal Stud. 115; Sol Piccioto, Regulating Global Corporate Capitalism (Cambridge: Cambridge University Press 2011).

151 Luc Fransen, 'Multi-stakeholder Governance and Voluntary Programme Interactions: Legitimation Politics In the Institutional Design of Corporate Social Responsibility' (2012) 10 Socio-Economic Review 163.

152 S414CZA, Companies Act.

153 But there is a clear pecking order in terms of shareholders' formal roles and powers in company law.

154 Margaret M Blair \& Lynn A Stout, “A Team Production Theory of Corporate Law” (1999) 85 Virginia. L. Rev. 247. 
Perhaps the Principles can provide examples to exhort profitable companies to ensure fair distribution, such as making appropriate wage improvements and pension contributions when profitable.

Finally, the manner of stakeholder engagement in the Principles can be improved towards the Habermasian model. One, companies identify and determine which stakeholder relationships to prioritise (Principle 6), and is chiefly in control of what is made accountable to stakeholders (Principle 6). Companies are to institute appropriate channels to receive stakeholder feedback and ensure this information is available to the highest levels of management (Principles 2, 3, 6) but only the workforce is explicitly provided with opportunities for 'two-way communications' (Principle 6). Such stakeholder engagement is firm and business-centred as companies determine which stakeholders to include, and would likely prioritise engagement based on the business case. This is likely no different from extant informal practices, and an opportunity could have been taken to promote two-way stakeholder communication in more open terms.

\section{Quality of Principles Relating to Self-Restraint in Advancing Private Preferences}

We argued earlier that in a large private company, the existence of private preferences is a given, but society and business would hypothetically bargain for self-restraint in advancing private preferences consistent with the benchmark norms in paragraph (a). As private preferences are often benefits that significant or controlling shareholders wish to extract for themselves, large private companies' corporate governance should address this issue. The Wates Principles addresses this in the following ways:

1. There should be effective and objective decision-making on Boards, although Boards are left to determine a suitable composition (including diversity considerations), such as appointing non-executive and independent directors and establishing Board committees with clear responsibilities (Principles 2, 3). Constructive challenge to decision-making should be encouraged (Principle 2). There is reference to maintaining directorial objectivity 'in particular where there is an influential shareholder' (Principle 2), suggesting that objective directors are a key means of ensuring the self-restraint of controlling interests. Further, encouraging constructive challenge is the Chairman's explicit role (Principle 2) and this is also seen as the way to mitigate 'any individuals having unfettered power' (Principle 3).

2. The transparency of internal affairs is encouraged, this includes having clear corporate governance practices, lines of accountability and responsibility in the company (Principle 3 ) and transparency in relation to shareholder agreements, parent company's relationships with subsidiaries and any minority shareholder relations (Principle 3 ).

3. There is specific provision for there to be transparency where subsidiary companies' executive remuneration policies are determined by their parent companies. Subsidiaries should explain clearly what the parent companies' policies are and how these affect subsidiaries (Principle 5).

We consider it a positive step that the Wates Principles addresses the need to moderate dominant or controlling influences on the Board. This is consistent with benchmark norm (b)b which posits that private preferences can result in behaviour that may be exploitative of stakeholders and the society, therefore inconsistent with the optimal benchmark norms under the social contract. This is an area of clear shortfall in extant business practices and was the key factor for the social scandal in BHS' collapse. Nevertheless, the Principles clearly see this to be a matter for self-regulation, that Boards should appoint suitably 'objective' people and be encouraged to engage in constructive 
challenge. Nevertheless, there is still clarity of responsibility in terms of how directors and Chairmen should conduct themselves.

However, if the Chairman is part of the controlling interest, the Chairman's role in objectively being able to distance himself/herself from bringing private preferences to bear can be doubted. Further, it is questioned why an alternative form of wording such as 'The Board shall ensure that its decisions are not unduly shaped by dominating forces or controlling interests in the company' is not adopted. Such wording makes it the collective responsibility of the Board to check the self-restraint of private preferences and is arguably more imperative than the current wording which suggests that the 'checking' and 'monitoring' roles are best performed by objective elements on the Board, which as Principle 3 proposes, are non-executive or independent directors. Ironically, making non-executive or independent appointments to the Board is an optional matter (Principle 2), as the provisions on optimal Board composition focus on balance of skills, expertise and diversity. It is queried how much priority the Principles give to the important issue of moderating private preferences, which is both theoretically and practically important (highlighted by lessons from BHS). We do not think making it more imperative for Boards to appoint non-executive or independent directors is necessarily the better way as directors that fulfil formal 'independence' criteria ${ }^{155}$ are not necessarily robustly objective in disposition, ${ }^{156}$ and such qualities are hard to prescribe. However we argue that our proposal on explicit collective Board responsibility to moderate private preferences could be usefully added to the Principles.

Further, as the moderation of private preferences also mitigates risks to stakeholders, we argue that this should be clearly identified as one of the risks to stakeholders in Principle 4. The Principle discusses business operations risks that may affect stakeholders but there should be inclusion too of corporate governance risks, as the example of BHS shows. Addressing these risks should be included in accountability to stakeholders (Principle 6). In this manner, the Wates Principles would more precisely address the concerns that have arisen from the BHS debacle that have damaged businesssociety relations.

Next, Principle 3 effectively supports the new corporate governance reporting obligation for large companies, ${ }^{157}$ which is an improvement over the existing state of affairs. Transparency in a large private company's corporate governance and structures of accountability have been opaque to the public, and such a context can facilitate the advancement of private preferences without sufficient scrutiny. However, we query to what extent transparency will be made in relation to shareholder agreements, agreements relating to minority shareholder relations and subsidiaries' relationships with their parent companies. It is noted that there is specific reference in Principle 5 to transparency and explanation of how parent companies influence their subsidiaries' executive remuneration policy. In general, shareholders' agreements are private and not required to be lodged as corporate documents. Even if companies report their existence, the terms are likely to remain private. In sum, we find the self-regulatory Board composition provisions and vague transparency provisions in Principles 2 and 3 are relatively modest in moderating private preferences that may result in behaviour that is exploitative of stakeholders or society. We further compare this position with that taken under the Listing Rules to regulate the advancement of private preferences in publicly listed companies that feature controlling interests.

\footnotetext{
${ }^{155}$ Such as a lack of employment or remuneration relationship defined in the UK Corporate Governance Code.

${ }^{156}$ Discussed in Dan W Puchniak and Luh Luh Lan, 'Independent Directors in Singapore Puzzling Compliance Requiring Explanation' (2015) 65 American Journal of Comparative Law.

${ }^{157}$ Part 8, Schedule 7 to the Companies Act 2006.
} 
In light of egregious behaviour in a few publicly listed companies on the London Stock Exchange adversely affecting minority shareholder interests, ${ }^{158}$ the Listing Authority introduced a regime to regulate the behaviour of controlling interests. ${ }^{159} \mathrm{~A}$ mandatory relationship agreement must be made between the controlling shareholder and the company in order to safeguard the company's independent commercial interests, prevent undue dependency on and interference by the controlling shareholder. ${ }^{160}$ The regime is self-enforcing as an independent director has to determine if there is a breach of the agreement in order to trigger the consequence of mandatory minority veto rights over all related-party transactions. This allows internal scrutiny and moderation of potential private benefit extraction. The hybrid mandatory-self-enforcing framework crucially relies on the robustness of independent directors and the ultimate scrutiny of the Listing Authority. ${ }^{161}$

We suggest that an adapted regime from the above that clarifies and reins in the relationship between controlling interests and the large private company can be adopted by the Wates Principles. It may be argued the regime only works because there are disinterested minority shareholders that check on controlling interests, this context is not relevant to many large private companies. In this way, the regime narrowly relates to protecting minority shareholders in listed companies only. Where large private companies have minority shareholders, we think the regime can similarly apply. It can be argued minority shareholders in a large private company have bought in voluntarily and with their eyes open and such shareholder relations should not be regulated by external standards. However, such an argument ignores the fact that even in closely-held companies, there can be inequality in bargaining power, seniority, experience, social status etc, and minority shareholders are not necessarily able to enter into optimal consensual shareholder agreements. ${ }^{162}$ Where the large private company is wholly-owned or there are no disinterested minorities, an adapted regime can still apply to subject private preferences to scrutiny. For example, a large private company could form a Board committee that is dedicated to monitoring private preferences, and make specific reporting on the work of the committee in the company's corporate governance report. In this manner, the Board committee safeguards the 'Purpose' of the company (Principle 1, also see below) and secures the company's conduct aligned with the benchmark norms in (a). This is not inconsistent with a 'stewardship' ${ }^{163}$ perspective of directors, as they inevitably mediate the interests of shareholders and stakeholders ${ }^{164}$ in contributing to value creation in the

\footnotetext{
158 The scandals relating to Bumi and ENRC as private interests became damaging to the company as a whole and affected minority shareholders" interests. See for example, 'Nat Rothschild set for showdown with Samin Tan as Bumi chairman raises stake in beleaguered business', The Independent (11 July 2013); 'ENRC 'should have set off alarm bells", Financial Times (22 November 2013). can thus effect a squeezeout of minority shareholders, eg in Essar's case, and they could delist. These are inevitable gaps in the regime and minority investors need to be aware where controlling interests are very strong. Further it is still being discussed as to whether the FCA may carve out state-owned companies from this regime, as the London Stock Exchange has been seeking to attract the listing of Saudi Aramco.

162 Many cases involving unfair prejudice petitions by minority shareholders feature inequalities in bargaining power eg Croly v Good [2010] EWHC 1 (Ch); Re Apollo Cleaning Services Ltd [1999] BCC 786.

163 J.H Davis, D.L. Schoorman and L Donaldson, 'The Distinctiveness of Agency Theory and Stewardship Theory' (1997) 22 Academy of Management Review 611.

164 Margaret M Blair \& Lynn A Stout, “A Team Production Theory of Corporate Law” (1999) 85 Virginia. L. Rev. 247.
} 
company. ${ }^{165}$ We also argue, on the basis of an extended perspective of the 'residual claimant', ${ }^{166}$ that directors would be rightly taking into account of constituents whose capital is tied up in an undiversified manner with the company, such as long-term employees, dedicated suppliers and pensioners in the company's defined benefit scheme (BHS), as they can be precisely identified and could stand to lose enormously if the company suffers misconduct or fails.

At a broader level, our proposal above also supports a more general connection between corporate governance at large private companies and their citizenship. Ultimately, the two are not unrelated as we have earlier argued why we evaluate the Wates Principles by the social contract construct and our derived benchmark norms. The Principles have become too firm and business-centred in terms of purpose (Principle 1), governance structures (Principles 2 and 5), and in considering stakeholder salience and engagement (Principles 4 and 6). These need to be connected back to the citizenship of large private companies in order to address the concerns that gave rise to these reforms.

\section{The Alignment of the Principles with Benchmark Norms}

We have argued that although the Principles provide for stakeholder engagement and addressing controlling influences, as envisaged in the procedural benchmark norms in (b), the provisions tend towards being too self-regulatory. This weakness may be attributed to the lack of underlying connection between the Principles as a procedural framework and the substantive benchmark norms in (a) that relate to business-society relations. In short, we posit that the Principles should address corporate governance as related to large private companies' citizenship. In light of the contextual and theoretical backgrounds discussed, the Principles are not just a set of best practices for business' internal use.

The business-centred focus of the Principles is seen in Principle 1 where the connection is not clearly made with citizenship. Principle 1 states that companies should develop and define their own 'Purpose'. Although there seems to be recognition of connecting to a more objective 'long-term sustainable value', the Principle clarifies explicitly that the Board must ultimately decide 'conflicts of interest' matters and trade-offs between short-term goals and long-term aspirations, upholding the company's strategic freedom. Further, we may critically query whether 'long-term sustainable value' is firm-centred value or a more holistic total value approach ${ }^{167}$ that includes business-society perspectives? Is 'sustainable' a term in relation to the company's business or to the wider environment? ${ }^{168}$ The domination of private freedom in this Principle is significant although the peppering of terms such as 'long-term sustainable value' may offer a form of vague moderation. Greenfield argues that the private freedom of a business to define its purpose can be taken to a logical anomaly, that is, allowing a company to privately define its purpose in an anti-social manner, such as the purpose of a drug cartel as raised in his example. ${ }^{169}$ It is arguably implicit that even for large private companies, corporate purpose cannot be isolated from business-society relations,

\footnotetext{
${ }^{165}$ Acknowledged in Principle 4.

${ }^{166}$ Margaret Blair, Ownership and Control: Rethinking Corporate Governance for the Twenty-First Century (Brookings Institute 1994); Arturo Capasso, 'Stakeholder Theory and Corporate Governance: The Role of Intangible Assets' at http://papers.ssrn.com/sol3/papers.cfm?abstract_id=610661.

${ }^{167}$ Such as the triple bottom line that includes measuring the value of the company beyond conventional shareholder-centred value measurements, such as by including social and environmental value (created or detracted).

168 Güler Aras and David Crowther, “Corporate Sustainability Reporting: A Study in Disingenuity?” (2009) 87 Journal of Business Ethics 279.

169 Kent Greenfield, Corporations are People Too (And They Should Act Like it) (NH: Yale University Press 2018) at ch1.
} 
which, according to the social contract theoretical construct we applied, must imbue tenets of citizenship as terms of a hypothetical fair bargain between business and society.

Further, Principle 1 refers to the Board's leadership in establishing policies to detect and deal with misbehaviour and unethical conduct. We consider it positive that it is Board responsibility to engage with respect for laws and regulations and to set the ethical tone and approach of the company. This seems aligned with the benchmark norms in (a)b-d. However, ethicality seems company-and business centred when read with the Principle's expectations that corporate values and culture are rallied around the company's purpose. There is an opportunity for ethicality to be defined in relation to a business-society moral compass, ${ }^{170}$ to encompass citizenship tenets as we have earlier suggested. As companies that we have surveyed have not shied away from adopting citizenship references, we are of the view that the Principles need not adopt an insular approach. A company's purpose can be framed in respect for its citizenship, and its culture can be aligned with citizenship and ethical standards.

\section{Conclusion}

We welcome the Wates Principles as a starting point for large private companies to adopt good practices and be accountable for their corporate governance. We argue however that these Principles ultimately form part of business-society relations as the reforms were prompted by social concerns arising out of the demise of BHS. We adopt the social contract theoretical construct to evaluate the Principles, pitching them against theoretically derived benchmark norms for large private companies (with relevant empirical input). While the Principles address aspects of procedural benchmark norms such as scrutinising controlling interests, and providing for stakeholder engagement, we are of the view that they do not sufficiently connect corporate governance to business-society relations.

170 Gary M Woller, 'Business Ethics, Society, and Adam Smith: Some Observations on the Liberal Business Ethos' (1996) 25 Journal of Socio-Economics 311; 